A Journal of Agricultural Science Published by the California Agricultural Experiment Station

CONTENTS

THE USE OF CHEMICAL DATA IN THE PROGNOSIS OF PHOSPHATE DEFICIENCY IN SOILS

JOHN S. BURD and H. F. MURPHY

\title{
THE RÔLE OF KAOLINITE IN PHOSPHATE FIXATION
}

H. F. MURPHY 
THE ROLE OF KAOLINITE IN PHOSPHATE FIXATION

H. F. MURPHY 


\section{CONTENTS}

PAGE

Phosphate-fixation systems. . . . . . . . . . . . . . . . . . . . . . . . . 343

Group 1 , chemical precipitation............................ 343

Group 2, mutual precipitation of phosphates by iron, aluminum, and silica

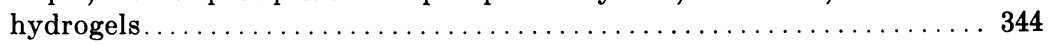

Group 3, adsorption of phosphates by alumino-silicates............ 345

General experimental methods. . . . . . . . . . . . . . . . . . . . . . 346

Influence of iron on phosphate fixation . . . . . . . . . . . . . . . . . 346

Iron hydrosols at different $\mathrm{pH}$ values in the presence of an excess of hydrosol 346

Iron phosphates at different $\mathrm{pH}$ values in the presence of an excess of iron . . . 348

Discussion of experiments with iron. . . . . . . . . . . . . . . . . . . 349

Studies on a soil having a high fixing power $\ldots \ldots \ldots \ldots \ldots \ldots \ldots \ldots \ldots \ldots \ldots \ldots \ldots$

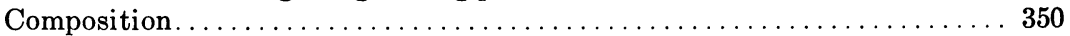

The release of phosphate by acid treatment.................. 350

The recovery of phosphate from superphosphate treatments with dilute

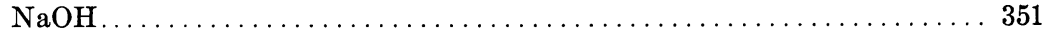

The recovery of phosphate from superphosphate treatments by acid equi-

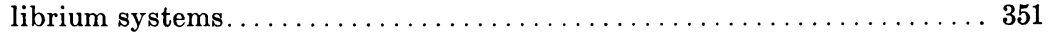

The recovery of phosphate from superphosphate treatments by acid leaching 353

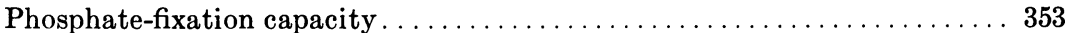

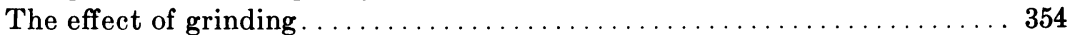

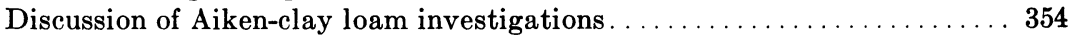

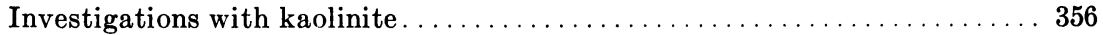

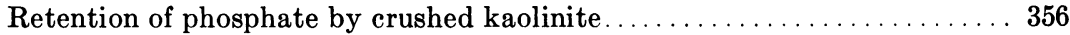

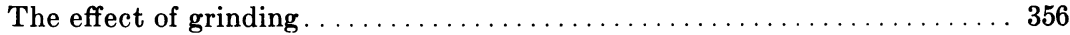

The effect of reaction as indicated by leaching................... 357

The effect of reaction as indicated by equilibrium study with $\mathrm{PO}_{4}$ constant 358

The effect of reaction as indicated by equilibrium study with both $\mathrm{K}$ and $\mathrm{PO}_{4}$

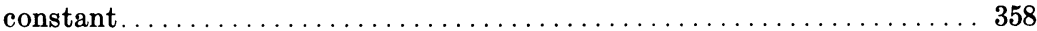

The effect of concentration on phosphate fixation $\ldots \ldots \ldots \ldots \ldots \ldots \ldots \ldots$

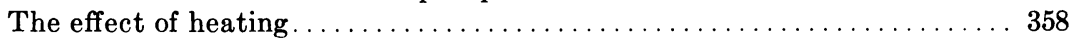

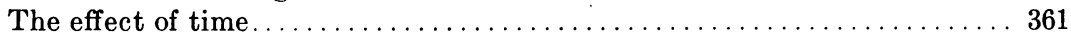

The effect of degree of saturation with respect to $\mathrm{PO}_{4}$ on cation exchange

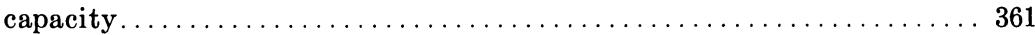

The effect of the oxalate ion on the adsorption of phosphate by kaolinite . . 362

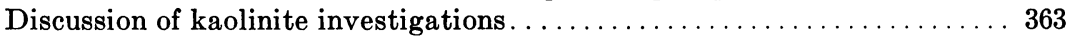

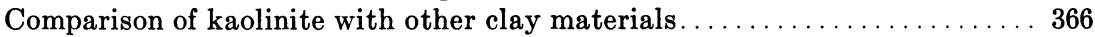

Greenhouse tests of phosphate fertilizer on Aiken clay loam . . . . . . . . . . . 367

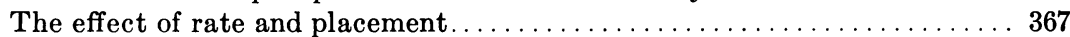

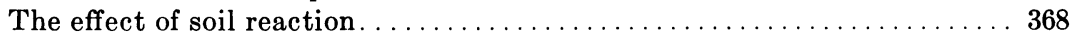

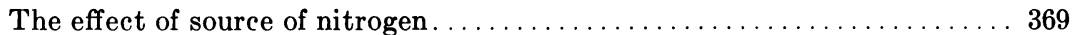

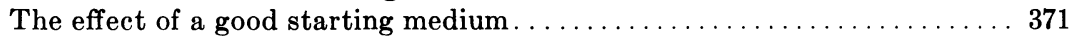

The effect of size of superphosphate particles................. 372

Greenhouse tests of comparative value of superphosphate and "kaolinite

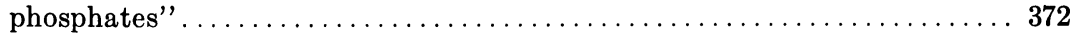

Greenhouse tests of the effect of various colloids on superphosphate efficiency 373

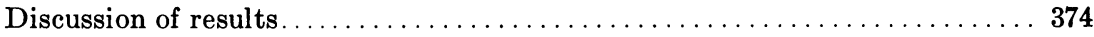

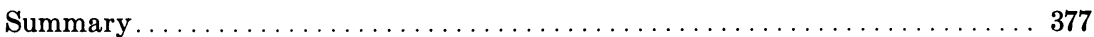

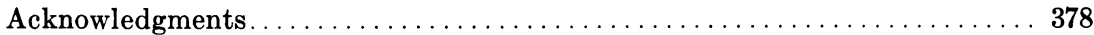

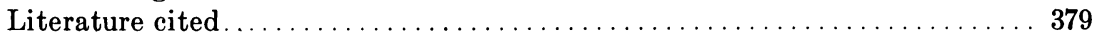




\title{
THE RÔLE OF KAOLINITE IN PHOSPHATE FIXATION ${ }^{1,2}$
}

\author{
H. F. MURPHY ${ }^{3}$
}

WHEN A SOLUBLE PHOSPHATE is brought in contact with the soil, reactions take place which remove a great deal, if not all, of the phosphate from solution. This phenomenon has been called "the fixation of phosphates by soils." Such a term carries no implication of the means by which removal takes place or of the product formed; it conveys only the idea that the phosphate has been changed and is present in some form that is only slightly soluble under the prevailing conditions. To the scientist who is interested in soil relations, plant relations, and the complex soil-plant system, more than the mere fact that the "phosphate is fixed by the soil" is required. The mechanism of the fixation is important to the soil specialist, while the means of resupplying the soil solution or the plant from the phosphate so held is important to the plant physiologist.

The investigations reported here were undertaken to obtain more fundamental data on the manner of phosphate fixation in soils not controlled by the calcium system.

\section{PHOSPHATE-FIXATION SYSTEMS}

The reactions converting phosphates into less soluble forms are several in number. The various types of fixation may now be classified into a few groups, which will be discussed in the following paragraphs.

Group 1, Chemical Precipitation.-Until rather recently, chemical precipitation has been considered the primary cause of phosphate fixation in all soils. This precipitation has been attributed largely to $\mathrm{Ca}, \mathrm{Fe}$, $\mathrm{Al}, \mathrm{Mg}$, and $\mathrm{Mn}$.

A great many soils are governed by what may be termed the "calcium system." Soils with such a system predominate in arid and semiarid regions and also occur in the more humid sections. In these soils, calcium is the predominating cation, although leaching may have removed it to a considerable degree. In some instances, leaching has been so severe that the only calcium left is found in a few local zones, and the soils are very acid. Such soils cannot be considered strictly within this group and will

\footnotetext{
${ }^{1}$ Received for publication June 22, 1938.

${ }^{2}$ Submitted in partial fulfillment of the requirement for the Degree of Doctor of Philosophy in the University of California.

${ }^{3}$ Graduate student of the University of California 1930-31, and 1937-38; now Associate Professor of Soils, Oklahoma Agricultural and Mechanical College.
} 
not be dealt with here. Where calcium is the controlling cation, it reacts with soluble phosphates and withdraws the phosphate ions from solution. Calcium phosphates, however, are appreciably soluble in an acid medium ; therefore, the production or introduction of a hydrogen-ion producing substance tends to redissolve the calcium phosphates formed.

Teakle $(46)^{4}$ has shown that calcium phosphates are relatively insoluble on the alkaline side of neutrality, and in the presence of an excess of calcium, they become insoluble at about $\mathrm{pH} 6$. This means that to liberate phosphate for plant use in such a system hydrogen ions must be produced in an amount sufficient to lower the $\mathrm{pH}$ at the absorbing surface below this value. Slightly acid soils belonging to this system and having an appreciable amount of calcium in the replaceable form are able to supply the plant with phosphate without difficulty, provided the potential supply is adequate. Gaarder and Nielsen (15) have shown the behavior of the phosphate ion in the presence of free ions of iron, aluminum, calcium, sodium, and magnesium.

In acid soils, the fixation of phosphates has been considered as due to the precipitation of $\mathrm{FePO}_{4}$ and $\mathrm{AlPO}_{4}$. The probability is against such a simple fixation, because free $\mathrm{Fe}$ and $\mathrm{Al}$ ions are not present in the soil solution to any appreciable extent except in very acid soils. That $\mathrm{FePO}_{4}$ and $\mathrm{AlPO}_{4}$ may be partially precipitated from an artificial system at $\mathrm{pH}$ ranges common to acid soils is ably shown by several investigators $(46,9)$, but this does not prove that $\mathrm{Fe}$ or $\mathrm{Al}$ ions are present in sufficient quantity to fix applied soluble phosphates rapidly. Moreover, certain experiments (32) have indicated the accessibility of such phosphates to plants at $\mathrm{pH}$ values of 6 and 7 . If $\mathrm{FePO}_{4}$ and $\mathrm{AlPO}_{4}$ were the products of fixation, it would seem that soils having a fair supply of phosphate and within this range of soil reaction should be able to supply the plant with the necessary phosphorus for growth. Truog (48) found that precipitated $\mathrm{FePO}_{4}$ and $\mathrm{AlPO}_{4}$ produced, with a few exceptions, good growth.

Group 2, Mutual Precipitation of Phosphates by Iron, Aluminum, and Silica Hydrogels.-Evidences of the adsorption type of reaction have accumulated during the last few years. Russell and Prescott (42) in 1916 ascribed some of their results to adsorption phenomena, but the criticism of their work by Fisher (11) and by Comber (5) discredited the idea for a time. In 1921 Harrison and Das (20) concluded that in noncalcareous soils the retention of $\mathrm{P}_{2} \mathrm{O}_{5}$ is mainly due to adsorption, whereas in calcareous soils retention by adsorption is either nonexistent or entirely masked by other causes. Shortly thereafter, the work of Gordon and his

\footnotetext{
"Italic numbers in parentheses refer to "Literature Cited" at the end of this paper.
} 
associates $(19,25,45)$ and of Mattson $(27-30)$ began to appear in the literature in support of a colloidal mechanism. Other recent investigations $(6,18,31,33,34,35,37,38)$ furnish confirming evidence of this kind of action.

The simpler iron and aluminum compounds found in the soil are oxides or hydrous oxides. While iron and aluminum ions may be present, the amount of these is appreciable only when the soil becomes very acid. The ordinary soil solution is very low in these ions as well as in phosphate ions. These facts lend support to the idea that the hydrated oxides of these materials, because of their colloidal nature, are responsible for considerable adsorption of phosphate ions. Heck (21) considers the active iron and aluminum in soils as existing in the forms of hydrated oxides.

Artificially prepared hydrogels and hydrosols of iron and aluminum have been shown $(16,25,45,47)$ to remove $\mathrm{PO}_{4}$ from solution. Gordon and his associates $(25,51)$ found that while iron and aluminum hydrogels were able to hold on to the adsorbed phosphate tenaciously against distilled water and certain sulfates, $0.1 \mathrm{~N}$ solutions of $\mathrm{NaOH}$ and $\mathrm{NH}_{4} \mathrm{OH}$ were capable of removing some of the adsorbed phosphate, and the plants were able to utilize $\mathrm{PO}_{4}$ from the freshly prepared material. Ellett and Hill (10) stated in 1917 that "if the yield is taken as a measure of availability, iron and aluminum do not fix phosphoric acid in forms unavailable to the wheat plant." In their experiments, they used iron and aluminum hydroxides as fixing agents for monocalcium phosphate and superphosphate (acid phosphate). Tiulin (47) prepared an iron gel of varying degrees of saturation of phosphate and showed that plants were able to secure phosphorus from it in accordance with the degree of saturation. Ford $(12,13)$ and Dean ( 7$)$ present evidence showing the formation of complex phosphate addition compounds to certain hydrated iron and aluminum oxides. Mattson (29) and Pugh (35) have demonstrated that the phosphate content of the iron or aluminum hydrogel complex is variable; it increases as $\mathrm{pH}$ is lowered and decreases as the $\mathrm{pH}$ is raised.

Group 3, Adsorption of Phosphates by Alumino-Silicates.-Mattson (30) shows that artificially prepared alumino-silicates as well as some naturally occurring colloids containing silica are capable of adsorbing phosphates, and that the $\mathrm{PO}_{4}$ content of the complex varies indirectly with $\mathrm{pH}$. Pugh and du Toit (36) report that silicates and phosphates may be regarded as substituted hydroxides, and that the $\mathrm{OH}$ ion replaces $\mathrm{SiO}_{3}$ and $\mathrm{PO}_{4}$ ions in exactly equivalent proportions in synthesized ferric silicates and phosphates.

Roszmann (40) suggests the possibility that the clay complex fixes 
phosphate. Bradfield (2) suggests that phosphates may in part be retained on the surfaces of the colloidal alumino-silicates in the soil, and that other anions may replace it. Scarseth (44) found that a prepared bentonite retained phosphate, and suggested that the adsorption on the colloidal surfaces at $\mathrm{pH} 5.5$ to 6.1 was due to the aluminum valence. "Ferriferated" bentonite increased the phosphate retained. The $\mathrm{PO}_{4}$ ion was found to be replaceable by $\mathrm{OH}$ and $\mathrm{SiO}_{4}$ anions.

Gilbert (17) reported that normal phosphate fertilization of some Rhode Island soils during a period of thirty-five years had not reduced the power of phosphate adsorption significantly, irrespective of the phosphate carrier used. A high rate of liming reduced the adsorption power. Furthermore, phosphate was fixed by these soils from buffer solutions of

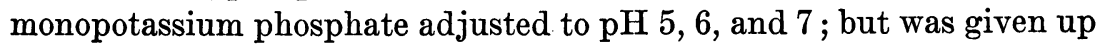
by the soil when the $\mathrm{pH}$ was lowered to 2 or was raised above 10 . Truog (48) showed that freshly precipitated iron and aluminum phosphates were utilizable by plants; but that after the first crops they were less so, and suggested that these older basic phosphates may have combined with acid silicates to form very resistant insoluble compounds.

\section{GENERAL EXPERIMENTAL METHODS}

The methods employed were varied according to the nature of the individual experiments and are described briefly in connection with these experiments. A few methods were common to many experiments, however, and these are described at this point to avoid repetition. The phosphates were determined volumetrically by the usual ammonium molybdate procedure. Potassium was determined volumetrically by titrating the precipitated potassium cobalti-nitrite with standard $\mathrm{KMnO}_{4}$. The $\mathrm{pH}$ values were determined by the glass electrode except in the greenhouse experiments, where the hydrogen electrode was employed. Where shaking was employed, it was generally done on rollers which turned the containers slowly along their horizontal axes. Exceptions to this shaking procedure will be noted.

\section{INFLUENCE OF IRON ON PHOSPHATE FIXATION}

Iron Hydrosols at Different $p H$ Values in the Presence of an Excess of $H y d r o s o l$. - In experiment 1a, a solution of $\mathrm{FeCl}_{3}$ was made of such concentration that when the other reagents were added, 500 cc contained $340 \mathrm{mg}$ of $\mathrm{Fe}$. The iron was precipitated as hydroxide at various $\mathrm{pH}$ values by the use of different amounts of dilute $\mathrm{NH}_{4} \mathrm{OH}$. A solution of $\mathrm{KH}_{2} \mathrm{PO}_{4}$ sufficient to furnish $175.6 \mathrm{mg}$ of $\mathrm{PO}_{4}$ was then added to make a total volume of $500 \mathrm{cc}$ in each case. The suspensions were shaken by 
hand, and after standing for about 1 day, the filtrates were tested for $\mathrm{PO}_{4}$. The results are given in table 1 .

TABLE 1

The Retention of Phosphate in the Presence of an Excess of Iron Hydrosol

\begin{tabular}{|c|c|c|c|c|}
\hline \multirow{2}{*}{ Color of filtrate } & \multicolumn{2}{|c|}{ Reaction } & \multicolumn{2}{|c|}{$\mathrm{PO}_{4}$ fixed } \\
\hline & Suspension & Filtrate & Amount & Per cent* \\
\hline Reddish amber...... & $\begin{array}{c}p H \\
2.13\end{array}$ & $\begin{array}{c}p H \\
2.14\end{array}$ & $\begin{array}{c}m g \\
15.60\end{array}$ & $\begin{array}{c}\text { per cent } \\
8.88\end{array}$ \\
\hline Clear amber....................... & 2.23 & 2.26 & 85.60 & 48.74 \\
\hline Very slightly yellow $\ldots \ldots \ldots \ldots \ldots \ldots$ & 2.53 & 2.64 & 173.35 & 98.72 \\
\hline Water-clear........... & 2.82 & 3.11 & 173.85 & 98.98 \\
\hline Water-clear. & 4.94 & 5.09 & 170.35 & 97.01 \\
\hline Water-clear. . & 6.50 & 6.50 & 129.60 & 73.80 \\
\hline Water-clear.......... & 7.36 & 7.32 & 110.60 & 62.98 \\
\hline 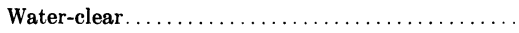 & 8.12 & 8.17 & 94.60 & 54.44 \\
\hline
\end{tabular}

* $\mathrm{PO}_{4}$ fixed as a percentage of that added.

The amount of iron $(340 \mathrm{mg}$ ) was arbitrarily chosen, but represents the amount removed from 100 grams of Aiken clay loam in citric acid (1:5) equilibrium extract. ${ }^{5}$ The exact procedure was to digest 10 grams of soil with 100 ec of $N$ citric acid on a steam bath for $1 / 2$ hour. The $\mathrm{PO}_{4}$ used was approximately equal to the total $\mathrm{PO}_{4}$ content of 100 grams of this soil.

TABLE 2

The Influence of $\mathrm{pH}$ on $\mathrm{FePO}_{4}$ Precipitation in the Presence OF AN EXCESS OF IRON

\begin{tabular}{|c|c|c|c|c|}
\hline \multirow{2}{*}{ Color of liquid } & \multicolumn{2}{|c|}{ Reaction } & \multicolumn{2}{|c|}{$\mathrm{PO}_{4}$ fixed } \\
\hline & Suspension & Filtrate & Amount & Per cent* \\
\hline & $p H$ & $p H$ & $m g$ & per cent \\
\hline Amber........ & 2.10 & 2.10 & 105.00 & 60.00 \\
\hline 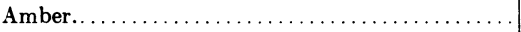 & 2.27 & 2.27 & 150.60 & 85.76 \\
\hline Slight amber $\ldots \ldots \ldots \ldots \ldots \ldots \ldots \ldots \ldots$ & 2.51 & 2.56 & 165.60 & 94.30 \\
\hline Slight yellow tinge $\ldots \ldots \ldots \ldots \ldots \ldots \ldots \ldots \ldots \ldots$ & 2.79 & 2.92 & 170.35 & 97.01 \\
\hline Water-clear. ........ & 3.17 & 3.47 & 174.35 & 99.29 \\
\hline Water-clear.... & 5.87 & 6.12 & 171.85 & 97.86 \\
\hline Water-clear. . . $\ldots \ldots \ldots \ldots \ldots \ldots \ldots \ldots \ldots \ldots$ & 7.33 & 7.30 & 175.35 & 99.86 \\
\hline 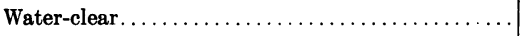 & 7.80 & 7.82 & 174.56 & 99.41 \\
\hline 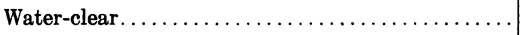 & 8.24 & 8.27 & 173.10 & 98.57 \\
\hline
\end{tabular}

* $\mathrm{PO}_{4}$ fixed as a percentage of that added.

In experiments $1 \mathrm{a}$ and $1 \mathrm{~b}$, the hydrosol was formed before adding the phosphate solution, whereas in experiments $2 a$ and $2 b$ the phosphate solution was added to the iron solution before adding the $\mathrm{NH}_{4} \mathrm{OH}$. This

${ }^{5}$ Hagan, R. M. Physiological deficiency in soils as related to mechanism of phosphate release. Unpublished manuscript. 1937. 
has a considerable bearing on the retention of $\mathrm{PO}_{4}$, as will be recognized in comparing the graphs in figures 1 and 2 . Figure 1, curve $a$, is a graphic representation of the data in table 1 .

In experiment $1 b$, the same procedure as in experiment $1 \mathrm{a}$ was used except that the amount of $\mathrm{FeCl}_{3}$ was only in slight excess of that neces-

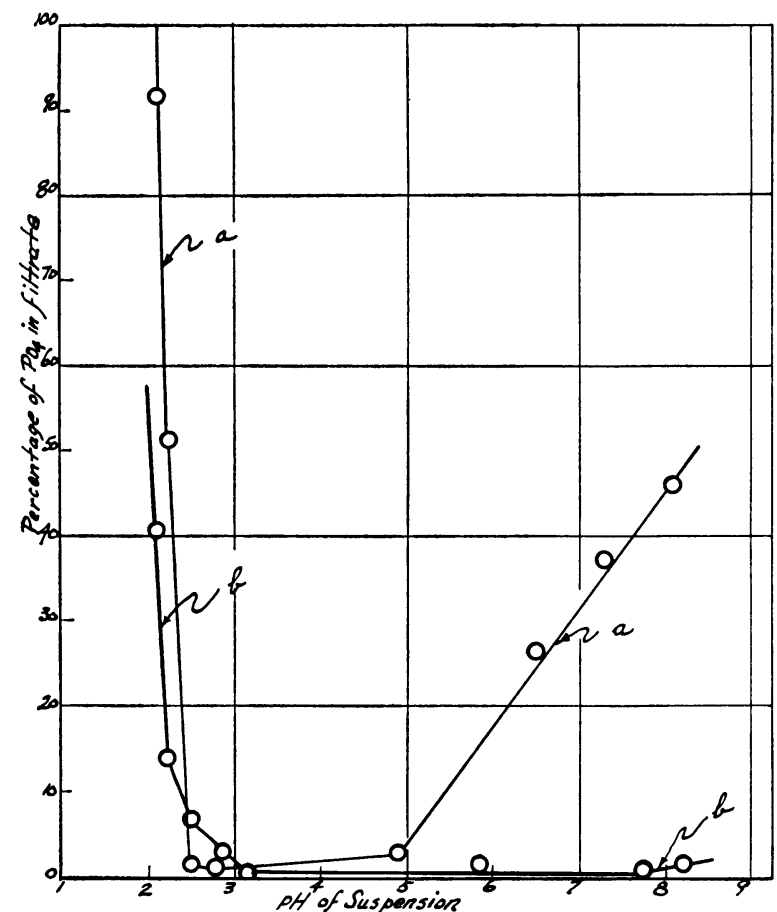

Fig. 1.-Curve $a$, the influence of $\mathrm{pH}$ on the adsorption of phosphate by an iron hydrosol containing a large excess of $\mathrm{Fe}$ over $\mathrm{PO}_{4}$; curve $b$, the influence of $\mathrm{pH}$ on the precipitation of phosphate in the presence of a large excess of Fe.

sary to combine with $\mathrm{PO}_{4}$ to give $\mathrm{FePO}_{4}$. The results are graphically represented in figure 2 , curve $a$.

Iron Phosphates at Different $p H$ Values in the Presence of an Excess of Iron.--In experiment 2a, a solution of $\mathrm{FeCl}_{3}$ was aảded to a $\mathrm{KH}_{2} \mathrm{PO}_{4}$ solution, and the $\mathrm{pH}$ was changed by adding various amounts of dilute $\mathrm{NH}_{4} \mathrm{OH}$. The total volume was $500 \mathrm{cc}$ and contained $340 \mathrm{mg}$ of $\mathrm{Fe}$ and $175.6 \mathrm{mg}$ of $\mathrm{PO}_{4}$. The shaking and period of standing were the same as in experiment 1a. The results are recorded in table 2 and are shown graphically in figure 1 , curve $b$.

In experiment $2 b$, the same procedure as in experiment $2 a$ was used except that the amount of $\mathrm{FeCl}_{3}$ employed was in only slight excess of 
that necessary to combine with the $\mathrm{PO}_{4}$ to give $\mathrm{FePO}_{4}$. The results are shown graphically in figure 2 , curve $b$.

Discussion of Experiments with Iron.-The data indicate that even in the presence of an excess of iron hydrosol an appreciable amount of $\mathrm{PO}_{4}$ is left in solution at $\mathrm{pH}$ values of 6 and above. Hence, if hydrous iron

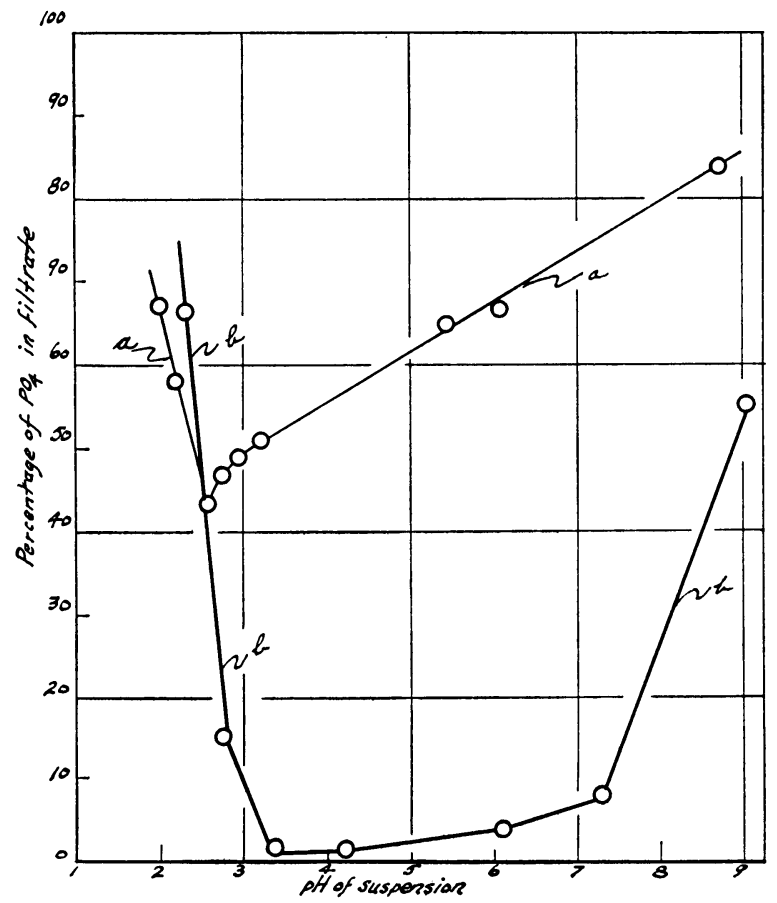

Fig. 2.-Curve $a$, the influence of $\mathrm{pH}$ on the adsorption of phosphate by an iron hydrosol containing only a slight excess of Fe over $\mathrm{PO}_{4}$; curve $b$, the influence of $\mathrm{pH}$ on the precipitation of phosphate in the presence of a slight excess of Fe.

oxides are functioning as the adsorbing system in a given soil, at $\mathrm{pH}$ values of about 6 there should be considerable $\mathrm{PO}_{4}$ in the soil solution available for plants, especially after applying a fertilizer containing soluble phosphate.

Not much iron is found in the soil solution until a high acidity is reached; therefore, the fixation as $\mathrm{FePO}_{4}$ (the $b$ curves in figs. 1 and 2) has a very limited effective range and could not account for rapid fixation in soils having only a slight acidity. Fixation by iron in such a $\mathrm{pH}$ range would be largely limited to the hydrous oxides present. Free nonhydrated iron oxide (hematite) has been found (13) unable to fix phosphate. 


\section{STUDIES ON A SOIL HAVING A HIGH FIXING POWER}

Certain soils have greater capacity to remove phosphates from solution than others. Colloids from such soils are characterized by having a low silica : sesquioxide ratio. The Aiken soil series is representative of this group and has been chosen for the studies involved.

Composition.-The composition of Aiken clay loam and its colloid was determined by the methods of the Association of Official Agricultural Chemists (1). The colloid was secured by placing $1 \mathrm{~kg}$ of soil in a 5 -gallon earthenware jar, agitating thoroughly each day, and removing the top $8 \mathrm{~cm}$ of suspension every 24 hours. This was carried out over a 30-day period. The suspension was filtered with Pasteur-Chamberlain filter tubes using suction. The chemical analyses of soil and colloid are given below :

\begin{tabular}{|c|c|c|}
\hline \begin{tabular}{r}
$\mathrm{SiO}_{2} \ldots \ldots \ldots \ldots \ldots \ldots$ \\
\multicolumn{1}{c}{$\ldots \ldots n s t i t u e n t$} \\
\end{tabular} & $\begin{array}{l}\text { Soil, per cent } \\
\ldots 38.63\end{array}$ & $\begin{array}{c}\text { Colloid, per cent } \\
30.98\end{array}$ \\
\hline $\mathrm{Fe}_{2} \mathrm{O}_{3} \ldots \ldots \ldots \ldots \ldots$ & $\ldots 12.42$ & 12.40 \\
\hline $\mathrm{Al}_{2} \mathrm{O}_{3} \ldots \ldots \ldots \ldots \ldots$ & $\ldots 34.43$ & 39.90 \\
\hline $\mathrm{CaO} \ldots$ & $\begin{array}{ll}\ldots & 1.68\end{array}$ & 1.68 \\
\hline MgO........... & 1.20 & 1.05 \\
\hline $\mathrm{PO}_{4} \ldots \ldots \ldots \ldots \ldots$ & 0.18 & 0.22 \\
\hline Ignition loss. $\ldots \ldots \ldots \ldots$ & 15.41 & 17.40 \\
\hline
\end{tabular}

The ratios were as follows :

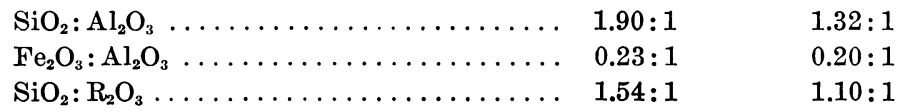

The percentage phosphate content of the colloid is higher than that of the soil. This is in accordance with data of other investigators $(3,12)$ who have made a study of the distribution of the chemical constituents in the various soil separates. It indicates that the finer fractions of the soil have a higher capacity for combining with soluble phosphates.

The Release of Phosphate by Acid Treatment.-Tests were made with $\mathrm{HCl}$ at various strengths on untreated Aiken clay loam. The ratio of soil to solution in each case was $1: 5$.

Such tests, if the acidity is great enough to dissolve appreciable quantities of iron and aluminum, should liberate increasing amounts of $\mathrm{PO}_{4}$ if the $\mathrm{PO}_{4}$ already present in the soil is in the form of iron or aluminum phosphate. Particularly is this the case if the $\mathrm{pH}$ is below 2.5, as is shown by figures 1 and 2 . The results (table 3 ) did not indicate any increase in the $\mathrm{PO}_{4}$ content of the filtrate with increase in $\mathrm{HCl}$ from equilibrium mixtures shaken for 1 hour. Evidently such minerals are absent; or if 
present, their presence is obscured by a secondary reaction involving clay minerals of a type discussed in a later section.

The Recovery of Phosphate from Superphosphate Treatments with Dilute $\mathrm{NaOH}$.-Four percolators were filled with air-dried Aiken clay loam. The cross-sectional soil area at the top of the percolator was equivalent to $1 / 500,000$ acre. The soil was moistened to field capacity with distilled water, and superphosphate of various-sized particles was placed

TABLE 3

$\mathrm{PO}_{4}$ Liberated from Aiken Clay LoAm by Different HCl SoLUTIONS

\begin{tabular}{|c|c|c|c|}
\hline $\begin{array}{l}\text { Approximate normality } \\
\text { of acid }\end{array}$ & $\begin{array}{l}\text { Reaction of } \\
\text { suspension }\end{array}$ & Fe in solution* & $\begin{array}{c}\mathrm{PO}_{4} \text { in filtrate } \\
\text { per } 100 \text { grams } \\
\text { of soil }\end{array}$ \\
\hline$N$ & $p H$ & & $m g$ \\
\hline $0.100 \ldots \ldots \ldots \ldots \ldots \ldots \ldots \ldots$ & 1.66 & +++ & $<0.2$ \\
\hline $0.075 \ldots \ldots \ldots \ldots \ldots \ldots \ldots$ & 1.68 & +++ & $<0.2$ \\
\hline $0.050 \ldots$ & 2.16 & ++ & $<0.2$ \\
\hline $0.025 \ldots \ldots \ldots \ldots$ & 2.93 & ++ & $<0.2$ \\
\hline $0.010 \ldots \ldots \ldots$ & 4.16 & Trace & $<0.2$ \\
\hline $0.002 \ldots$ & 5.64 & None & $<0.2$ \\
\hline $0.001 \ldots$ & 5.83 & None & $<0.2$ \\
\hline
\end{tabular}

* As shown by $\mathrm{NH}_{4} \mathrm{OH}$ precipitation.

on top of the moistened soil surface of each percolator at the rate of 600 pounds per acre. The soils were leached with distilled water until 2,000 cc of leachate was secured from each percolator. This required approximately 2 days. The samples were allowed to stand in the percolators and air-dry for one week. They were then divided into layers. A 1:5 suspension of each of the various soil layers in $0.1 \mathrm{~N} \mathrm{NaOH}$ was made. The samples were shaken 1 hour, filtered, and the $\mathrm{PO}_{4}$ content of the filtrate was determined.

Sodium hydroxide was chosen as a medium because numerous experiments (50 and unpublished data ${ }^{6}$ ) have shown that low figures are secured from its use if the $\mathrm{PO}_{4}$ in the soil is controlled by a calcium equilibrium system; furthermore, high figures are secured where the phosphate is in the form of iron or aluminum phosphate or is held by adsorption. Hydrolysis of iron and aluminum phosphates occurs as the $\mathrm{pH}$ is increased above $\mathrm{pH} 7(15,26,46)$.

The results are reported in table 4.

The Recovery of Phosphate from Superphosphate Treatments by Acid Equilibrium Systems.-Previous experiments, ${ }^{7}$ as well as those performed by the writer (table 3 ), show that ordinary acid equilibrium

\footnotetext{
${ }^{B}$ Burd, J. S., unpublished data.

' Hagan, R. M. Physiological deficiency in soils as related to mechanism of phosphate release. Unpublished manuscript. 1937.
} 
extractions of this soil give practically no $\mathrm{PO}_{4}$ in the filtrate. However, according to table 4, more of the added phosphate remained in the soil as a calcium phosphate when larger rather than when small particles of

TABLE 4

The Influence of Particle Size on the Recovery of $\mathrm{PO}_{4}$ From SUPERPHOSPHATE BY $0.1 N \mathrm{NaOH}$

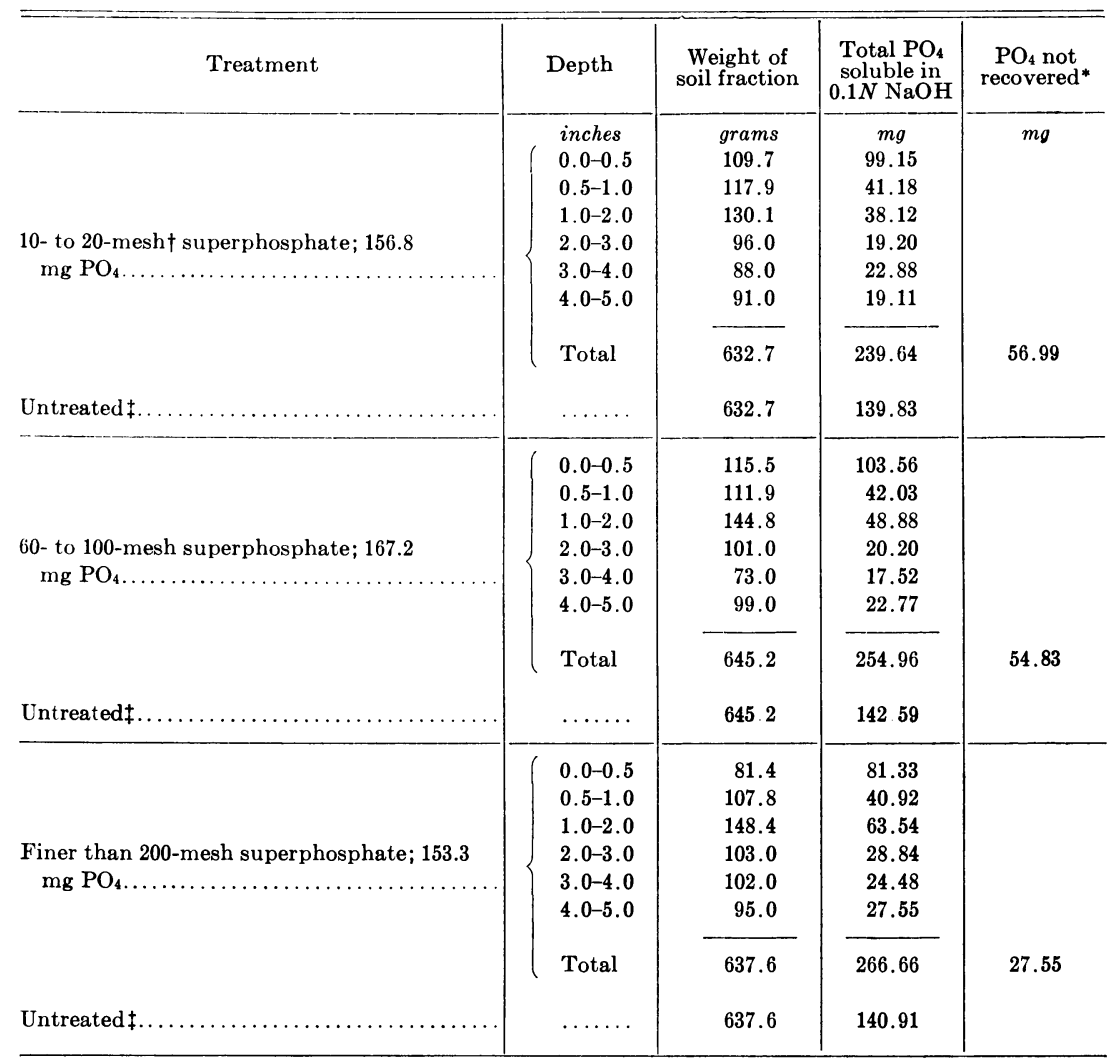

* This is calculated from the amount of $\mathrm{PO}_{4}$ added in the superphosphate, the amount of $\mathrm{PO}_{4} 0.1 \mathrm{~N}$ $\mathrm{NaOH}$ extracted from untreated soil, and the amount of $\mathrm{PO}_{4}$ the $\mathrm{NaOH}$ actually extracted from the treated soil. sieve.

$\ddagger 0.1 \mathrm{~N} \mathrm{NaOH}$ removed $22.10 \mathrm{mg}$ of $\mathrm{PO}_{4}$ from!100 grams of untreated soil.

superphosphate were used; these results indicate that perhaps an acid extraction would give a further indication of this amount.

Accordingly, the equivalent of 20 grams of moisture-free soil from the 0.0-0.5-inch layer of each treatment was shaken for 1 hour with $\mathrm{HCl}$ so as to furnish a 1:5 filtrate with a $\mathrm{pH}$ of 3 . The results are shown in table 5 . 
The experiment is inconclusive, since the acid may have dissolved the residual calcium phosphate; and this may have been immediately adsorbed by the soil colloids.

The Recovery of Phosphate from Superphosphate Treatments by Acid Leaching.-The purpose of acid leaching was to determine if, during the $\mathrm{HCl}$ equilibrium experiment, any phosphate was dissolved which was subsequently fixed.

Three 100-gram samples of Aiken clay loam were weighed out, one was

TABLE 5

HCl Equilibrium and HCl Leaching Studies of Aiken Clay Loam * AFTER TREATING WITH SUPERPHOSPHATE

\begin{tabular}{|c|c|c|c|}
\hline \multirow{2}{*}{ Fineness of superphosphate used } & \multicolumn{2}{|c|}{ HCl equilibrium studies* } & \multirow{2}{*}{$\begin{array}{l}\mathrm{HCl} \text { leaching- } \\
\mathrm{PO}_{4} \text { in filtrate } \\
\text { per } 100 \text { grams } \\
\text { of soil } \dagger\end{array}$} \\
\hline & $\begin{array}{l}\text { Reaction of } \\
\text { suspension }\end{array}$ & $\begin{array}{c}\mathrm{PO}_{4} \text { in filtrate } \\
\text { per } 100 \text { grams } \\
\text { of soil }\end{array}$ & \\
\hline 10 - to 20 -mesh.. & $\begin{array}{c}p H \\
3.07\end{array}$ & $\begin{array}{l}m g \\
0.2\end{array}$ & $\begin{array}{c}m g \\
29.77\end{array}$ \\
\hline 60 - to 100 -mesh $\ldots \ldots \ldots \ldots \ldots \ldots \ldots \ldots \ldots$ & 3.07 & 0.2 & $\ldots$ \\
\hline Finer than 200 mesh $\ldots \ldots \ldots \ldots \ldots \ldots \ldots \ldots$ & 2.99 & 0.2 & 15.04 \\
\hline None............................... & 2.93 & 0.2 & Trace \\
\hline
\end{tabular}

* 20 grams of soil from 0.0-0.5-inch layer of treatment in table 4 used in this experiment.

$\dagger 560 \mathrm{mg}$ of superphosphate per $100 \mathrm{grams}$ of soil used.

treated with $560 \mathrm{mg}$ of 10 - to 20-mesh superphosphate, one was treated with $560 \mathrm{mg}$ of superphosphate finer than 200-mesh, and no phosphate was added to the third.

The superphosphate was thoroughly mixed with the soil. The samples were placed in pint jars and 50 ce of distilled water were added. The jars were loosely closed to prevent evaporation and were kept at room temperature for 8 days. At the end of this time, the soil was removed from each jar and spread out in a thin layer over 15-cm filter papers in Buechner funnels. Each sample was leached rapidly with 500 ec of $0.1 \mathrm{~N} \mathrm{HCl}$, filtering being hastened by suction. The time required was 5 minutes. Samples of the filtrates were tested for their phosphate content. The results are tabulated in table 5.

Phosphate-Fixation Capacity.-Samples of 100 grams of Aiken clay loam were shaken for 1 hour with 500 ec of water and enough monocalcium phosphate to furnish the amounts of $\mathrm{PO}_{4}$ shown in table 6 . The samples were filtered, and the $\mathrm{PO}_{4}$ content of the filtrates was determined.

The residues were re-treated with the same quantities of monocalcium phosphate as in the first treatment, and the rest of the procedure repeated. In table 6 are also recorded the amounts of $\mathrm{PO}_{4}$ fixed by this second treatment, and the combined fixation for both treatments. 
The Effect of Grinding.-A 75-gram charge of the Aiken clay loam was ground in a ball mill for 6 days. Its ability to fix phosphate was determined along with that of unground soil, Aiken colloid, and kaolinite that had been ball-milled for 9 days.

The procedure followed was to weigh out 1-gram samples into small bottles; add 50 ce of $\mathrm{KH}_{2} \mathrm{PO}_{4}$ solution ( $\mathrm{pH} 4.48$ ) containing a total of $355.24 \mathrm{mg}$ of $\mathrm{PO}_{4}$, and shake for 100 hours. After the shaking process, the suspensions were allowed to stand for 1 day to permit the settling out of the solid materials. The $\mathrm{PO}_{4}$ content of the filtrates was then determined. The results were as follows :

\begin{tabular}{|c|c|c|}
\hline Substance & $\mathrm{pH}$ of filtrate & $\begin{array}{l}\mathrm{PO}_{4} \text { fixed per } 100 \\
\text { grams of soil, } \mathrm{mg}\end{array}$ \\
\hline Aiken clay loam......... & . . 5.22 & 2,372 \\
\hline Aiken clay loam, ball-milled. & 5.89 & 6,232 \\
\hline Aiken colloid $\ldots \ldots \ldots \ldots \ldots$ & 5.51 & 3,858 \\
\hline Kaolinite, ball-milled, 9 days & 6.07 & 10,988 \\
\hline
\end{tabular}

Discussion of Aiken-Clay-Loam Investigations.-The analyses (p. 350) indicate that the soil chosen for the study has a low silica :sesquioxide ratio, and that the total iron content is much the same in the colloidal and noncolloidal fractions.

If all the iron in the soil were active and free to combine with $\mathrm{PO}_{4}, 100$ grams of the soil would be able to fix approximately 14.7 grams of $\mathrm{PO}_{4}$. If only the iron in the clay fraction is active (calculation would indicate approximately 50 per cent of the soil is colloidal matter) the 100 grams of soil would be able to fix about 7.3 grams of $\mathrm{PO}_{4}$.

The 100 grams of soil (table 6), after two exposures to a high concentration of monocalcium phosphate, retained approximately 2.5 grams of $\mathrm{PO}_{4}$. This would require that between 25 and 30 per cent of the iron in the clay fraction be active and free to combine. If the soil had been treated with more phosphate, more $\mathrm{PO}_{4}$, would probably have been fixed.

Unpublished data ${ }^{8}$ indicate that normal citric acid removes approximately one-third of a gram of iron from 100 grams of this soil. Assuming that this is all the iron that is free to react with $\mathrm{PO}_{4}$, it could combine with only about 0.6 grams of $\mathrm{PO}_{4}$. The soil actually retained more than four times this amount (table 6). The $\mathrm{pH}$ of normal citric acid is 1.82 , which is much below $\mathrm{pH} 4.26$, the $\mathrm{pH}$ of the filtrate after fixation from the high concentration of monocalcium phosphate ; and that much acidity should bring into solution, if not all, at least most, of the iron which is free to react with the phosphate to form $\mathrm{FePO}_{4}$ or the iron phosphate complexes.

\footnotetext{
${ }^{8}$ Hagan, R. M. Physiological deficiency in soils as related to mechanism of phosphate release. Unpublished manuscript. 1937.
} 
The active iron that could be instrumental in the fixation process must be of a hydrous oxide form and have sufficient surface exposure. In view of the amount dissolved by citric acid, iron of this character could scarcely be present in sufficient amount.

After the soil is ground in the ball mill, its ability to fix phosphate increases very greatly, which would indicate other factors are entering into the problem of phosphate fixation in this soil.

The fixation capacity is extremely high, and therefore saturating the soil with phosphate would apparently be impractical. When a heavy application is made, however, some phosphate is left for plant use.

TABLE 6

Phosphate Fixation by Aiken Clay Loam with Two Monocalcium Phosphate Treatments

\begin{tabular}{|c|c|c|c|c|c|c|c|c|}
\hline \multirow{2}{*}{$\begin{array}{c}\text { Sample } \\
\text { No. }\end{array}$} & \multirow{2}{*}{$\begin{array}{l}\mathrm{PO}_{4} \text { added } \\
\text { (each } \\
\text { treatment) }\end{array}$} & \multirow{2}{*}{$\begin{array}{l}\mathrm{PO}_{4} \text { in } \\
\text { filtrate }\end{array}$} & \multicolumn{6}{|c|}{$\mathrm{PO}_{4}$ fixed per $100 \mathrm{grams}$ of soil } \\
\hline & & & \multicolumn{2}{|c|}{ First treatment } & \multicolumn{2}{|c|}{ Second treatment } & \multicolumn{2}{|c|}{ Total } \\
\hline $1 \ldots$ & $\begin{array}{l}m g \\
25.26\end{array}$ & $\begin{array}{l}m g \\
0.35\end{array}$ & $\begin{array}{l}m g \\
24.29\end{array}$ & $\begin{array}{c}\text { per cent } \\
96.16\end{array}$ & $\begin{array}{l}m g \\
23.61\end{array}$ & $\begin{array}{c}\text { per cent } \\
93.47\end{array}$ & $\begin{array}{l}m g \\
47.90\end{array}$ & $\begin{array}{c}\text { per cent } \\
94.81\end{array}$ \\
\hline $2 \ldots$ & 125.91 & 2.55 & 123.36 & 97.97 & 109.00 & 86.57 & 232.36 & 92.27 \\
\hline $3 \ldots$ & 624.85 & 152.61 & 472.24 & 75.58 & 275.41 & 44.08 & 747.65 & 59.83 \\
\hline $4 \ldots \ldots$ & $3,125.76$ & $1,693.93$ & $1,431.83$ & 45.81 & $1,036.65$ & 33.16 & $2,468.48$ & 39.49 \\
\hline
\end{tabular}

The low figures secured with the acid treatments on the fertilized soil (table 5) indicate a high degree of fixation and precludes the presence of much calcium phosphate. These data, however, do not tell where the fixation took place in the soil column.

Since $\mathrm{NaOH}$ extracts give large figures for iron, aluminum, and colloidally formed phosphates, they can be used to determine in which soil layers the fixation occurred. The data in table 4 show that extreme fixation took place in the surface $1 / 2$ inch of soil and in no case was there any appreciable penetration of the applied phosphate below a depth of 2 inches.

The larger particles of fertilizer appear to have some advantage over the finer particles in retaining their phosphate as calcium phosphate in the soil. This is indicated by the acid-leaching data given in table 6 . Because of the limited leaching, these figures cannot be taken as the total amount of calcium phosphate present, but they represent a high percentage of it.

A concentrated $\mathrm{HCl}$ digestion of the coarse particles which were removed from the acid-leached soil showed that they contained a total of $21 \mathrm{mg}$ of $\mathrm{PO}_{4}$. Hence, the coarse particles after a week's contact with moist soil retained less than one-third of their original phosphate content. 


\section{INVESTIGATIONS WITH KAOLINITE}

The failure to secure an increase in released $\mathrm{PO}_{4}$ (table 3, p. 351) when the soil was extracted with $\mathrm{HCl}$ at $\mathrm{pH} 2$ and lower (the reaction at which phosphated iron hydrosol and iron phosphate are both soluble) lead to an investigation of the type of clay present in the soil, and its capacity to remove phosphate from solutions. $\mathrm{X}$-ray investigations showed that the

TABLE 7

The Retention of Phosphate by Crushed Kaolinite (Suspension* shaken 1 hour)

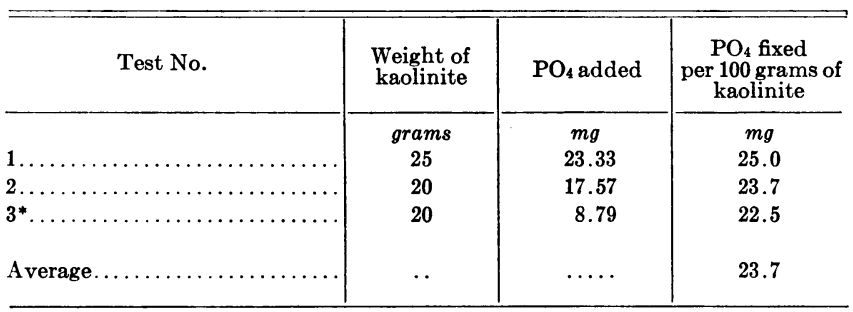

* 1.0:5.0 suspension for tests 1 and 2, 1.0:2.5 suspension for test 3 .

clay was kaolinic in character (fig. $3, B$ ). Data presented on page 350 show it to have a low silica : sesquioxide ratio.

Retention of Phosphate by Crushed Kaolinite.-Since the clay was so identified, samples of crushed kaolinite were tested for their ability to fix phosphate from a 1:5 suspension of dilute monocalcium phosphate. The shaking was for a 1-hour period.

The results are recorded in table 7.

The rather coarse kaolinite used fixed $\mathrm{PO}_{4}$ at the rate of $23.7 \mathrm{mg}$ per 100 grams. This establishes a rather high fixing power even for fairly coarse kaolinite, and immediately suggests a probable source of fixation for soils (containing kaolinite) whose fixing capacity cannot be assigned to precipitation by calcium or to mutual precipitation with iron or aluminum hydrosols.

The Effect of Grinding.-In an experiment to determine the effect of fineness of kaolinite upon the quantity of $\mathrm{PO}_{4}$ fixed, a sample of 125 grams of kaolinite was placed in a ball mill for 6 days. At the end of this time all but 50 grams was removed. The 50 -gram charge was left in the mill, and at intervals 1-gram samples were removed. The ability of the various samples ground for different periods of time to fix phosphate was determined. In making this determination, 1-gram samples were placed in small bottles with 50 ec of $\mathrm{KH}_{2} \mathrm{PO}_{4}$ solution containing $6.8 \mathrm{mg}$ of $\mathrm{PO}_{4}$ per ec and having a $\mathrm{pH}$ of 4.47. The suspensions were shaken on a roller 
for 100 hours. They were removed and allowed to settle for 1 day, when the phosphate content of the supernatant liquid was determined.

The results are recorded in table 8 . Grinding increased immensely the capacity of the kaolinite to retain phosphate. Since the kaolinite in the soil is in a finely divided condition, it must have a great capacity to fix phosphate.

The Effect of Reaction as Indicated by Leaching.-A solution of $\mathrm{KH}_{2} \mathrm{PO}_{4}$ was modified by the addition of $\mathrm{NaOH}$ and water so as to give

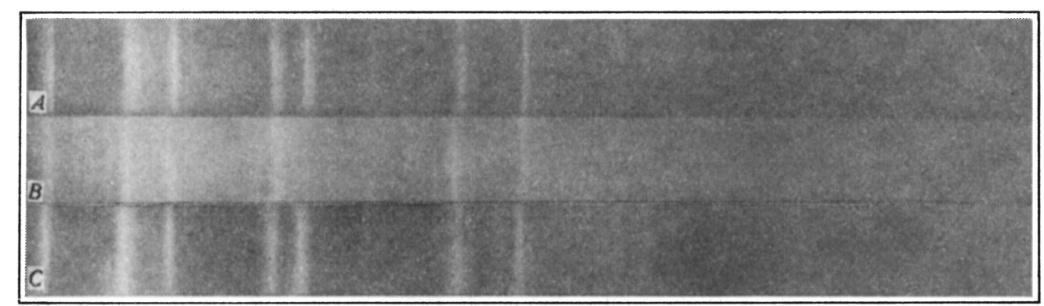

Fig. 3.-X-ray photographs: $A$, of the kaolinite used in the experiments; $B$, of the Aiken colloid; $C$, of a referee sample of kaolinite.

solutions having $\mathrm{pH}$ values of $4.54,6.23,6.43$, and 7.90. Each of these solutions had the same $\mathrm{K}$ and $\mathrm{PO}_{4}$ content (1.1 and $2.8 \mathrm{mg}$ per cc, respectively), but the sodium content varied according to the amount of $\mathrm{NaOH}$ necessary to change the $\mathrm{pH}$. Kaolinite, which had been ground in a ball mill for 5 days in a 150-gram charge and then 2 days in a 75-gram charge,

TABLE 8

The Efrect of Grinding Kaolinite on Phosphate Fixation

(1: 50 suspension with $\mathrm{KH}_{2} \mathrm{PO}_{4}$ solution per $100 \mathrm{cc}$; shaken 100 hours)

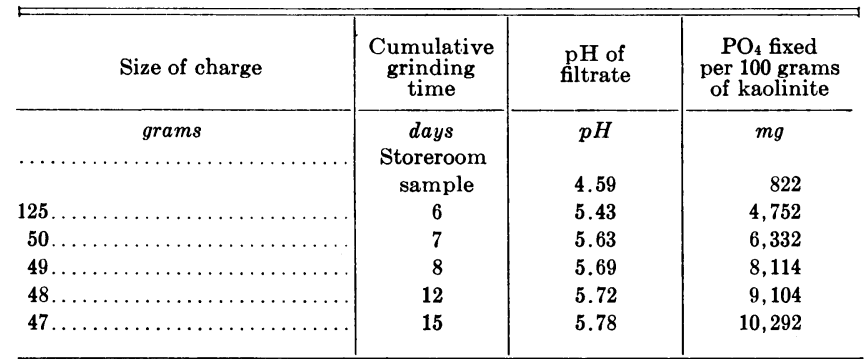

was weighed out in four 10-gram lots, placed in beakers; and $100 \mathrm{cc}$ of solution was added, a different solution being placed in each beaker. The beakers and their contents were warmed in a water bath at $70^{\circ} \mathrm{C}$ for 3 hours. The suspensions were filtered with suction. The residue was then washed with three additional portions (15 cc, $50 \mathrm{cc}$, and $25 \mathrm{cc}$ ) of the 
same phosphate solution as had been used earlier. The $\mathrm{PO}_{4}$ content of the solutions less that in the filtrates was considered as the phosphate fixed by the kaolinite. The results are given in table 9 .

The Effect of Reaction as Indicated by Equilibrium Study with $\mathrm{PO}_{4}$ Constant.-One-gram samples of kaolinite, which had been ground in a ball mill for 7 days in a 75-gram charge, were suspended in 50-cc portions of solutions of $\mathrm{KH}_{2} \mathrm{PO}_{4}$ with different $\mathrm{pH}$ values. This amount of phos-

TABLE 9

The Fixation of Phosphate at Various Reactions bY KaOLinite and Its INFLUENCE ON THE REACTION OF THE Filtrate

\begin{tabular}{c|c|c|c}
\hline \multicolumn{2}{c|}{ Reaction } & $\begin{array}{c}\mathrm{PO}_{4} \text { fixed } \\
\text { per 100 grams of } \\
\text { kaolinite }\end{array}$ & $\begin{array}{c}\text { K fixed } \\
\text { per 100 grams } \\
\text { of kaolinite }\end{array}$ \\
\cline { 1 - 2 } $\begin{array}{c}\text { Original } \\
\text { solution }\end{array}$ & Filtrate & $m g$ & $m g$ \\
\hline$p H$ & $p H$ & $m g$ & 342.5 \\
4.54 & 6.20 & $1,956.7$ & $491.7(?)$ \\
6.23 & 6.40 & $1,243.3$ & 409.3 \\
6.43 & 6.40 & 863.8 & 452.9 \\
7.90 & 7.24 & 274.9 & \\
\hline
\end{tabular}

phate solution contained $98.55 \mathrm{mg}$ of $\mathrm{PO}_{4}$. The $\mathrm{pH}$ was adjusted by the addition of $\mathrm{KOH}$. The suspensions were shaken for 6 hours, and after standing 1 day, the supernatant liquid was analyzed.

The results are summarized in table 10.

The Effect of Reaction as Indicated by Equilibrium Study with Both $K$ and $\mathrm{PO}_{4}$ Constant.-Solutions of $\mathrm{H}_{3} \mathrm{PO}_{4}, \mathrm{KOH}$, and $\mathrm{KCl}$ were mixed and made to volume to give solutions with different $\mathrm{pH}$ values but with a constant $\mathrm{PO}_{4}$ and $\mathrm{K}$ content : 50 ce contained $183.8 \mathrm{mg}$ of $\mathrm{K}$ (except where otherwise noted) and $160.7 \mathrm{mg}$ of $\mathrm{PO}_{4}$. One-gram samples of kaolinite ground as in the preceding experiment were suspended in $50 \mathrm{cc}$ of each solution. The suspensions were shaken for 20 hours, then centrifuged, and the supernatant liquid analyzed immediately. The results are given in table 11.

The Effect of Concentration on Phosphate Fixation.-The effect of the concentration of $\mathrm{KH}_{2} \mathrm{PO}_{4}$ on phosphate fixation was studied in connection with different amounts of kaolinite which had been ground in a ball mill for 7 days. The total volume of solution was $25 \mathrm{cc}$ in all cases. The kaolinite was weighed out in series of 1.0-gram, 2.5-gram, and 5.0-gram samples and one sample of each weight was added to each $\mathrm{KH}_{2} \mathrm{PO}_{4}$ solution. The suspensions were shaken for 12 hours, allowed to stand 7 days, filtered, and the filtrates were analyzed. The results are given in table 12.

The Effect of Heating.-According to several investigators $(24,39)$, kaolinite breaks down when heated to $450-500^{\circ} \mathrm{C}$. This does not neces- 
sarily mean that the new complex would not be able to fix phosphate, however.

Two 1-gram samples of kaolinite ground in a 150-gram charge for 5

TABLE 10

The Fixation of Phosphate by Kaolinite in an Equilibrium System

\begin{tabular}{c|c|c|c|c|c|c|c}
\hline \multicolumn{2}{c|}{ Reaction } & \multicolumn{2}{|c|}{ Content of solution* } & \multicolumn{2}{c|}{ Content of filtrate } & \multicolumn{2}{c}{$\begin{array}{c}\text { Amount fixed per } \\
100 \text { grams of kaolinite }\end{array}$} \\
\hline $\begin{array}{c}\text { Original } \\
\text { solution }\end{array}$ & Filtrate & $\mathrm{K}$ & $\mathrm{PO}_{4}$ & $\mathrm{~K}$ & $\mathrm{PO}_{4}$ & $\mathrm{~K}$ & $\mathrm{PO}_{4}$ \\
\hline$p H$ & $p H$ & $m g$ & $m g$ & $m g$ & $m g$ & $m g$ & $m g$ \\
4.56 & 6.12 & 38.45 & 98.55 & 34.19 & 79.30 & 426 & 1,925 \\
6.66 & 6.80 & 52.99 & 98.55 & 45.18 & 87.17 & 781 & 1,138 \\
7.70 & 7.62 & 71.45 & 98.55 & 62.27 & 95.20 & 918 & 335 \\
\hline
\end{tabular}

* A 50-cc portion of solution was shaken with 1 gram of kaolinite.

days in a ball mill were weighed out. One of these was heated to $500^{\circ} \mathrm{C}$ for 70 hours ; the other was left unheated. Each was shaken with a solution of $\mathrm{KH}_{2} \mathrm{PO}_{4}(\mathrm{pH} 4.60)$ containing $98.55 \mathrm{mg}$ of $\mathrm{PO}_{4}$ for 18 hours, and the amount of $\mathrm{PO}_{4}$ fixed in each case was determined. There was no appreciable difference in the amount of $\mathrm{PO}_{4}$ fixed, each fixing approximately $1,000 \mathrm{mg}$ per 100 grams. The loss in weight during the heating period was 0.1345 gram. The $\mathrm{pH}$ of the filtrate after fixation in each case was 5.78.

TABLE 11

The Fixation of Phosphate from Solutions Having Different ph Values, BUT Where THe $\mathrm{K}$ aND $\mathrm{PO}_{4}$ CONTENTS Were KePt CONSTANT

\begin{tabular}{|c|c|c|c|c|c|}
\hline \multirow{2}{*}{$\begin{array}{l}\text { Amount } \\
\text { of } K \text { in } \\
\text { solution }\end{array}$} & \multicolumn{2}{|c|}{ Reaction } & \multirow{2}{*}{ Source of $\mathbf{K}$} & \multirow{2}{*}{$\begin{array}{c}K \text { fixed per } \\
100 \text { grams of } \\
\text { kaolinite }\end{array}$} & \multirow{2}{*}{$\begin{array}{c}\mathrm{PO}_{4} \text { fixed } \\
\text { per } 100 \\
\text { grams of } \\
\text { kaolinite }\end{array}$} \\
\hline & Solution & Filtrate & & & \\
\hline 183.8 & $\begin{array}{r}p H \\
1.87 \\
1.90 \\
5.41 \\
6.88 \\
10.09 \\
12.24\end{array}$ & $\begin{array}{r}p H \\
3.15 \\
3.07 \\
5.91 \\
6.83 \\
8.03 \\
10.51\end{array}$ & $\begin{array}{l}\text { None } \\
100 \text { per cent } \mathrm{KCl} \\
60 \text { per cent } \mathrm{KCl}, 40 \text { per cent } \mathrm{KOH} \\
40 \text { per cent } \mathrm{KCl}, 60 \text { per cent } \mathrm{KOH} \\
20 \text { per cent } \mathrm{KCl}, 80 \text { per cent } \mathrm{KOH} \\
100 \text { per cent } \mathrm{KOH}\end{array}$ & $\begin{array}{c}m g \\
\ldots \\
591 \pm \\
475 \pm \\
423 \pm \\
1,105 \\
2,248\end{array}$ & \begin{tabular}{r}
\multicolumn{1}{c}{$m g$} \\
13,776 \\
13,587 \\
3,068 \\
2,281 \\
619 \\
None
\end{tabular} \\
\hline 36.8 & $\begin{array}{l}1.85 \\
2.31\end{array}$ & $\begin{array}{l}3.05 \\
5.15\end{array}$ & $\begin{array}{l}100 \text { per cent } \mathrm{KCl}^{*} \\
100 \text { per cent } \mathrm{KOH}^{*}\end{array}$ & $\begin{array}{l}162 \\
529\end{array}$ & $\begin{array}{r}13,646 \\
9,529\end{array}$ \\
\hline
\end{tabular}

* One-fifth the $\mathrm{K}$ content of the others.

In another case where 1 gram of kaolinite was heated at $450-550^{\circ} \mathrm{C}$ for 50 hours and subjected to shaking for 100 hours in contact with $50 \mathrm{cc}$ of $\mathrm{KH}_{2} \mathrm{PO}_{4}$ solution ( $\mathrm{pH} 4.43$ ) containing $432.4 \mathrm{mg}$ of $\mathrm{PO}_{4}$, it fixed 53.6 $\mathrm{mg}$ of $\mathrm{PO}_{4}$ as compared with $67.2 \mathrm{mg}$ fixed by an unheated sample. The $\mathrm{pH}$ of the filtrate from the unheated sample was 5.87. 


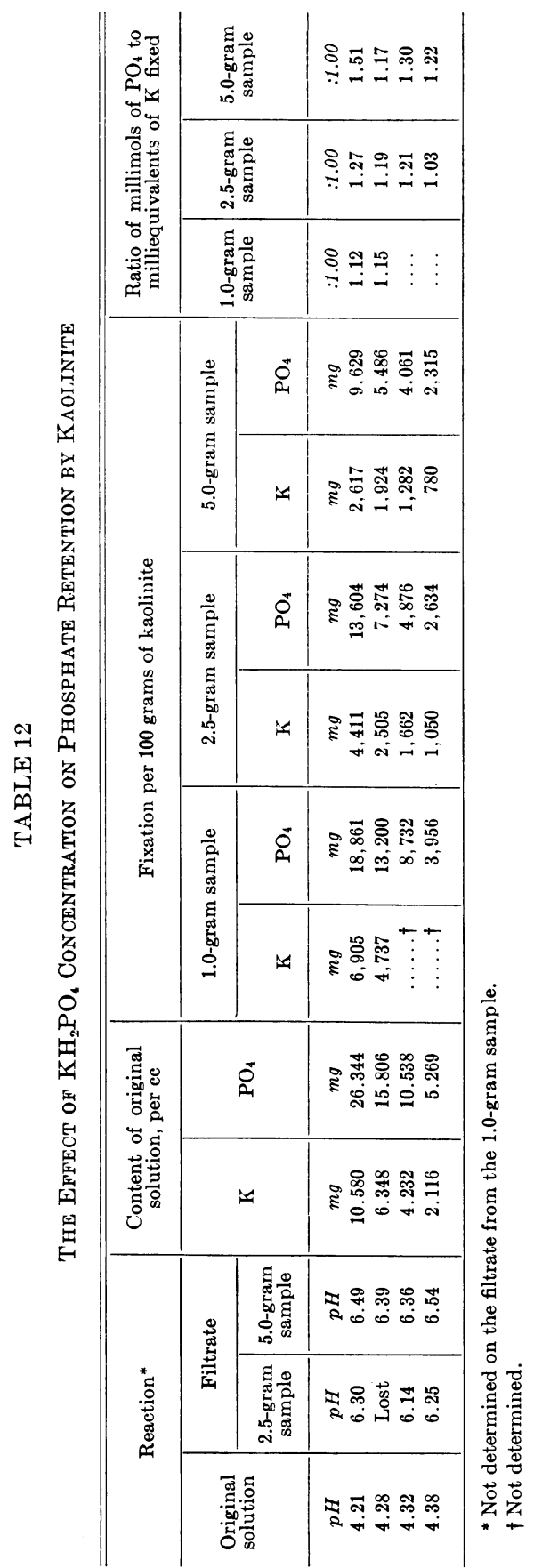


Heating to $500^{\circ} \mathrm{C}$, which destroys the crystal structure as revealed by X-ray data, apparently has little effect in reducing the capacity of kaolinite to fix phosphate.

The Effect of Time.-Time $(6,14,22)$ has been shown to be of considerable importance in phosphate fixation. This was studied by using two

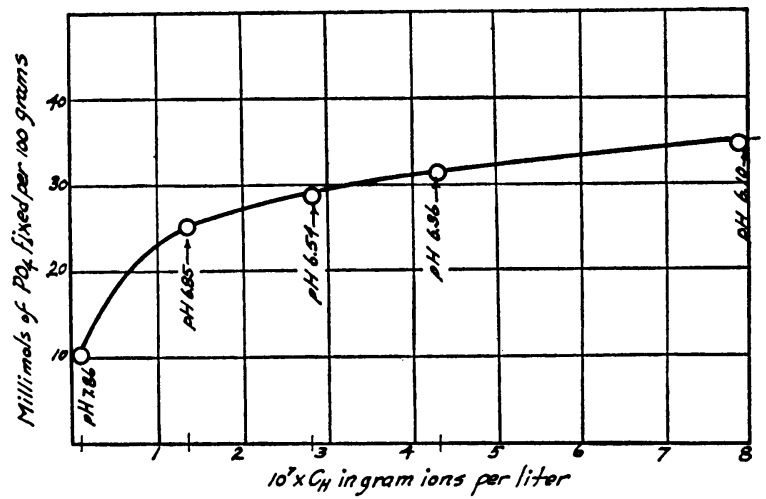

Fig. 4.-The relation between hydrogen-ion concentration of equilibrium solution and phosphate fixed. (Data taken from table 18.)

5 -gram samples of finely ground kaolinite suspended in 50 ec of $\mathrm{KH}_{2} \mathrm{PO}_{4}$ solution. One of the suspensions was shaken for 4 hours and the other for 5 days.

The results are recorded in table 13 . The data show very clearly that time is an element of importance in the fixation process, but even so, the fixation after a short exposure is of considerable magnitude.

TABLE 13

The Influence of Time on Phosphate Fixation by Kaolinite

\begin{tabular}{|c|c|c|c|}
\hline Time of exposure & $\begin{array}{l}\mathrm{PO}_{4} \text { in original } \\
\text { solution* }\end{array}$ & $\mathrm{PO}_{4}$ in filtrate & $\begin{array}{l}\mathrm{PO}_{4} \text { fixed per } 5 \\
\text { grams of kaolinite }\end{array}$ \\
\hline 4 hours $\ldots \ldots \ldots \ldots \ldots \ldots \ldots \ldots \ldots \ldots \ldots \ldots \ldots \ldots \ldots$ & $\begin{array}{c}m g \\
1,242.32\end{array}$ & $\begin{array}{c}m g \\
928.72\end{array}$ & $\begin{array}{c}m g \\
313.60 \\
682.10\end{array}$ \\
\hline 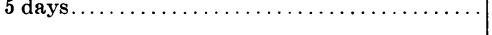 & $1,242.32$ & 560.22 & 082.10 \\
\hline
\end{tabular}

* Shaken with 5 grams of kaolinite.

The Effect of Degree of Saturation with Respect to $\mathrm{PO}_{4}$ on Cation Exchange Capacity.- "Kaolinite phosphates" of different degrees of saturation were made by suspending ground kaolinite in solutions of $\mathrm{KH}_{2} \mathrm{PO}_{4}$ of different concentrations. After adsorption, the samples were filtered; and the residues were washed with distilled water and air-dried. The degree of phosphate saturation of the kaolinite samples was determined by analyzing the solutions before and after exposure. The base- 
exchange capacity of the "kaolinite phosphates" was determined by the usual neutral normal ammonium acetate method used in the Plant Nutrition Laboratory. The results are shown in table 14 and in figure 5.

TABLE 14

The Base-Exchange Capacity of "Kaolinite Phosphates" of Difrerent Degrees OF PHOSPHATE SATURATION

\begin{tabular}{|c|c|c|c|c|}
\hline \multicolumn{2}{|c|}{ Material } & \multicolumn{2}{|c|}{ Exchange capacity } & \multirow{2}{*}{$\begin{array}{c}\mathrm{PO}_{4} \text { fixed } \\
\text { per } 100 \text { grams }\end{array}$} \\
\hline Type & $\begin{array}{c}\mathrm{PO}_{4} \text { per } \\
\text { gram }\end{array}$ & $\begin{array}{l}\text { Per } 100 \\
\text { grams }\end{array}$ & $\begin{array}{l}\text { Increase per } \\
100 \text { grams }\end{array}$ & \\
\hline & $m g$ & $\begin{array}{c}\text { milli- } \\
\text { equivalents }\end{array}$ & $\begin{array}{c}\text { milli- } \\
\text { equivalents }\end{array}$ & millimols \\
\hline Kaolinite............. & 0.0 & 26.85 & $\ldots$ & \\
\hline “Kaolinite phosphate". & 14.55 & 31.92 & 5.07 & 15.31 \\
\hline "Kaolinite phosphate". & 20.45 & 34.96 & 8.11 & 21.62 \\
\hline "Kaolinite phosphate". & 36.37 & 41.05 & 14.20 & 36.29 \\
\hline "Kaolinite phosphate".. & 64.68 & 50.68 & 23.83 & 68.08 \\
\hline
\end{tabular}

The Effect of the Oxalate Ion on the Adsorption of Phosphate by Kaolinite.-One-gram samples of ground kaolinite were treated with different ratios of $0.1 \mathrm{~N} \mathrm{H}_{3} \mathrm{PO}_{4}$ to $0.1 \mathrm{~N}$ oxalic acid. The total volume in all cases was $50 \mathrm{cc}$. The suspensions were shaken for 6 hours and the phosphate and oxalate ions in the filtrates were determined. The oxalate ion

TABLE 15

The Fixation of Phosphate in the Presence and Absence OF THE OXALATE ION

( 1 gram of kaolinite used)

\begin{tabular}{|c|c|c|c|c|c|c|c|}
\hline \multirow[b]{2}{*}{$\mathrm{H}_{3} \mathrm{PO}_{4}$} & \multicolumn{5}{|c|}{ With oxalate ions present } & \multicolumn{2}{|c|}{ With no oxalate ions } \\
\hline & $\begin{array}{l}\text { Amount } \\
\text { of oxalic } \\
\text { acid }\end{array}$ & Al in solution & $\begin{array}{c}\text { Reaction } \\
\text { of } \\
\text { filtrate }\end{array}$ & $\begin{array}{l}\mathrm{PO}_{4} \text { fixed } \\
\text { per gram of } \\
\text { kaolinite }\end{array}$ & $\mathrm{C}_{2} \mathrm{O}_{4}$ fixed & $\begin{array}{c}\text { Reaction } \\
\text { of } \\
\text { filtrate }\end{array}$ & $\begin{array}{l}\mathrm{PO}_{4} \text { fixed } \\
\text { per gram of } \\
\text { kaolinite }\end{array}$ \\
\hline$c c$ & $c c$ & & $p H$ & $m g$ & $m g$ & $p H$ & $m g$ \\
\hline 50.0 & $\ldots$ & & $\ldots$ & $\ldots \ldots$ & $\ldots$ & 3.42 & 134.32 \\
\hline 37.5 & 12.5 & $+t$ & 3.28 & 72.35 & $?$ & 3.79 & 105.66 \\
\hline 25.0 & 25.0 & $++t$ & 3.42 & 20.21 & 2.20 & 4.06 & 71.63 \\
\hline 12.5 & 37.5 & $+t+t$ & 3.13 & 0.28 & None & 4.80 & 34.99 \\
\hline 0.0 & 50.0 & $+t+t+$ & 2.52 & -0.39 & 2.20 & $\ldots$ & $\cdots \cdots$ \\
\hline
\end{tabular}

in an $\mathrm{H}_{2} \mathrm{SO}_{4}$ solution was titrated against standard potassium permanganate. The aluminum content of the filtrates was qualitatively studied.

In another series no oxalic acid was added, but the same amounts of $0.1 N \mathrm{H}_{3} \mathrm{PO}_{4}$ were used as in the various mixtures with the volumes made up by adding distilled water. The filtrates from the latter series contained only a trace of aluminum. A comparison of the results is given in table 15. 
In a study of $\mathrm{KH}_{2} \mathrm{PO}_{4}$ and oxalic acid systems at the same $\mathrm{pH}$ values, three different solutions were made to a $\mathrm{pH}$ of $4.8-4.9$ as follows :

Solution 1. $-50 \mathrm{ec}$ of $\mathrm{KH}_{2} \mathrm{PO}_{4}$ solution $+60 \mathrm{ce}$ distilled water. Solution 2 . $-50 \mathrm{cc}$ of $\mathrm{KH}_{2} \mathrm{PO}_{4}$ solution +50 ce $0.1 \mathrm{~N}$ oxalic acid +4.6 ec water +5.4 ce $N \mathrm{KOH}$. Solution 3. -50 ec of $0.1 \mathrm{~N}$ oxalic acid $+54.8 \mathrm{ec}$ water $+5.2 \mathrm{ce} N \mathrm{KOH}$.

A 1-gram sample of kaolinite was suspended in 50 ce of each of these solutions. The suspensions were shaken for 4 hours and allowed to stand 12 hours before centrifuging. The filtrates were analyzed and the results tabulated (table 16). There was no aluminum present in any of the filtrates, as observed from ammonium hydroxide precipitation.

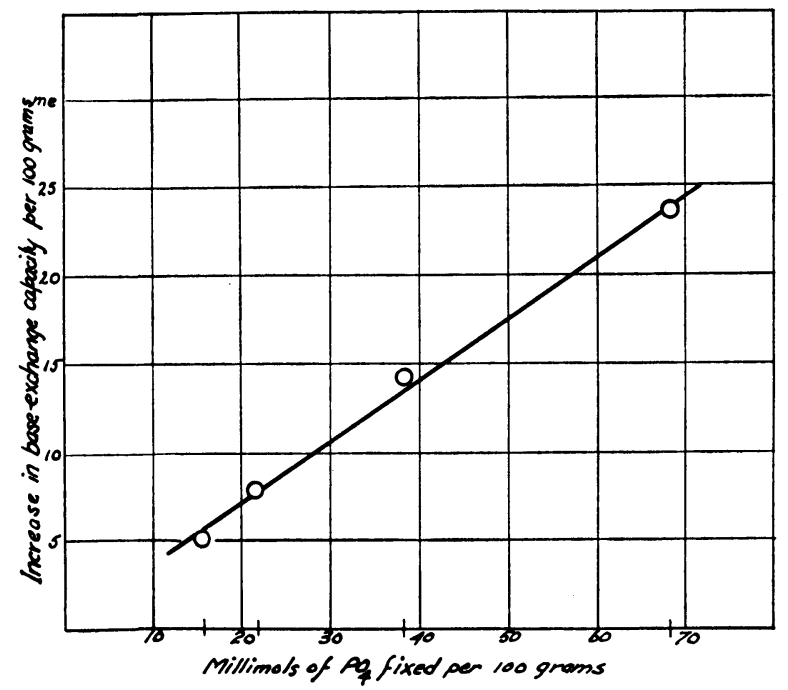

Fig. 5.-The relation of phosphate fixation by kaolinite to increase in base-exchange capacity.

The presence of the oxalate ion decreases the amount of phosphate fixed. In the previous experiment (table 15), this was probably due to the breakdown of the kaolinite (as evidenced by the aluminum in solution) because of the low $\mathrm{pH}$ of the initial solution. In the case of the experiment with $\mathrm{KH}_{2} \mathrm{PO}_{4}$ (table 16 ), there was no apparent decomposition of the kaolinite, yet there was much less phosphate fixed. The exact reason for the decrease in phosphate fixation is not apparent in this case.

Discussion of Kaolinite Investigations.-Kaolinite when finely ground (table 8) has great capacity to fix phosphate. The hydrogen-ion concentration is an important factor in the fixation process, but since the fixation is of great magnitude in the reaction range of agricultural soils, any soil possessing a kaolinic clay will exhibit this fixing power to a high degree. The fixation decreases as the $\mathrm{OH}$-ion concentration increases 
(tables $9,10,11,13$ ); at high $\mathrm{pH}$ values (table 11) the kaolinite complex is unable to adsorb phosphate. This is in opposition to cation fixation by kaolinite, which increases with increasing $\mathrm{OH}$-ion concentration.

Since the magnitude of the fixation of phosphate is greatest in the acid range, the $\mathrm{H}_{2} \mathrm{PO}_{4}$ ion must play a considerable rôle. As indicated by figure 4 and data (table 17) prepared by Buehrer (4), as long as the hydrogen-ion concentration is sufficient to permit the presence of the $\mathrm{H}_{2} \mathrm{PO}_{4}$ ion, phosphate is fixed. At the higher $\mathrm{pH}$ values, the increased fixation of $\mathrm{K}$ (cation) lowers the $\mathrm{pH}$ of the filtrate. When the drop in $\mathrm{pH}$

TABLE 16

The Flxation of Phosphate and Oxalate Ions from Solutions HAVING AN INITIAL $\mathrm{pH}$ of $4.8-4.9$

( 1 gram of kaolinite used)

\begin{tabular}{c|c|c|c|c}
\hline \multirow{3}{*}{$\mathrm{PO}_{4}$ added } & $\mathrm{C}_{2} \mathrm{O}_{4}$ added & \multicolumn{3}{|c}{ Fixation per gram of kaolinite } \\
\cline { 2 - 5 } & & $\mathrm{PO}_{4}$ & $\mathrm{C}_{2} \mathrm{O}_{4}$ & $\mathrm{~K}$ \\
\hline$m g$ & $m g$ & $m g$ & $m g$ & $m g$ \\
47.85 & 0.0 & 13.93 & $\ldots$. & 4.54 \\
47.85 & 100.0 & 7.37 & 2.2 & 6.82 \\
0.00 & 100.0 & $\ldots \ldots$ & 2.2 & Not determined \\
& & & & \\
\hline
\end{tabular}

(increase in hydrogen-ion concentration) is not sufficient to bring about the formation of the $\mathrm{H}_{2} \mathrm{PO}_{4}$ ion, the magnitude of phosphate fixation is small. Hence, the fixation is roughly proportional to the percentage of $\mathrm{H}_{2} \mathrm{PO}_{4}$ ions in the solution. The fixation of some phosphate in the $\mathrm{pH}$ range of 8 to 10 indicates that $\mathrm{HPO}_{4}$ ions enter into the process to some extent.

The concentration of the phosphate solution (table 12) has an influence on the degree of phosphate saturation of the kaolinite. The higher the concentration the more nearly saturated will the kaolinite complex become. When a small amount of kaolinite is suspended in a concentrated phosphate solution, it fixes a relatively large amount of the soluble phosphate, while a large amount of kaolinite will fix practically all of the phosphate if the quantity of soluble phosphate is not extremely great. This has a practical application in the use of the phosphate fertilizers on soils having this type of clay.

As the kaolinite complex increases in phosphate content, its baseexchange capacity increases proportionally to the amount of phosphate fixed (table 14 and figure 5). Mattson (27-30) showed that phosphated "sesquioxides possess a high cation-exchange capacity, and that certain soil colloids possessed this increased exchange capacity when they had adsorbed phosphate. This he attributed to an increase in the acidoid con- 
tent of the complex through the adsorption of a polyvalent ion. The data in table 14 substantiate the results of Mattson. Since the data further indicate the importance of the $\mathrm{H}_{2} \mathrm{PO}_{4}$ ion and $\mathrm{HPO}_{4}$ ion at the higher $\mathrm{pH}$ values, one of the possible reactions is as follows : $3 \mathrm{CH}_{3} \mathrm{COONH}_{4}+\mathrm{HO}$ $\left[\mathrm{Si}(\mathrm{OH})_{\mathrm{m}} \mathrm{Al}\right] \mathrm{H}_{2} \mathrm{PO}_{4} \rightarrow \mathrm{NH}_{4} \mathrm{O}\left[\mathrm{Si}(\mathrm{OH})_{\mathrm{m}} \mathrm{Al}\right]\left(\mathrm{NH}_{4}\right)_{2} \mathrm{PO}_{4}+3 \mathrm{CH}_{3} \mathrm{COOH}$. The $(\mathrm{OH})_{\mathrm{m}}$ designates $\mathrm{OH}$ groups which are nonreactive under the prevailing conditions.

When the $\mathrm{pH}$ of the extracting solution is somewhere below $\mathrm{pH} 1.5-2.0$ and the ratio of solution to kaolinite is great (mass action), the kaolinite

TABLE 17

Concentration of Phosphate Ions in Solution at Various Hydrogen-Ion Concentrations Based on aN Assumed Total Concentration OF 1 PART PER MrLLION* OF $\mathrm{PO}_{4}$

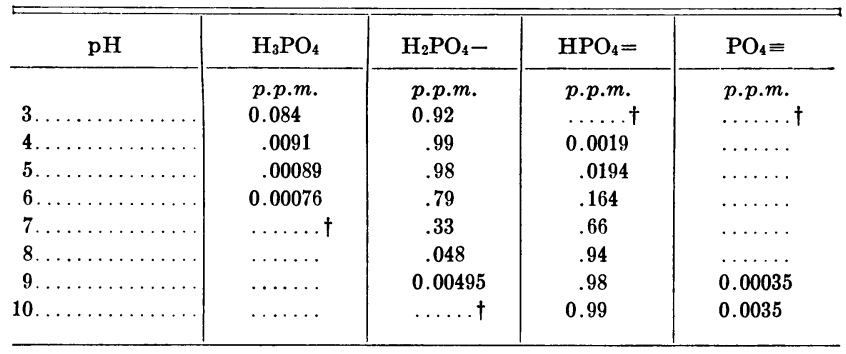

* From Buehrer (4).

† The blank spaces denote insignificant values for the purpose involved.

begins to break down, and as a result, its ability to fix phosphate decreases. When the $\mathrm{pH}$ approaches a value of 1 , there is a complete loss of ability to fix phosphate. This effect was produced when a 1-gram sample of kaolinite was shaken for 10 hours with $50 \mathrm{cc}$ of $\mathrm{HCl}$ of $\mathrm{pH}$ 1.2. The filtrate had a high aluminum content. The residue fixed very little phosphate, either from a solution of $\mathrm{H}_{3} \mathrm{PO}_{4}(\mathrm{pH} 1.9)$, or from a solution of $\mathrm{KH}_{2} \mathrm{PO}_{4}(\mathrm{pH} 4.3$ ). Before treating with the $\mathrm{HCl}$, a sample of the original kaolinite fixed between 140 and $160 \mathrm{mg}$ of $\mathrm{PO}_{4}$ per gram. Apparently a breakdown of the kaolinite took place in the oxalic-acid and $\mathrm{H}_{3} \mathrm{PO}_{4}$ series. The initial acidity was such that it broke down some of the kaolinite and prevented as much fixation as occurred when only $\mathrm{H}_{3} \mathrm{PO}_{4}$ of $\mathrm{pH} 1.9$ was used. The oxalic acid had a $\mathrm{pH}$ of 1.6 and the $\mathrm{pH}$ of the $\mathrm{H}_{3} \mathrm{PO}_{4}$ and oxalic acid mixtures must have been somewhere between these values.

Decomposition also occurs when the concentration of $\mathrm{OH}$ ion becomes sufficient. A $0.1 N \mathrm{NaOH}$ solution decomposes kaolinite to a slight extent. When the $\mathrm{KOH}$ and $0.1 \mathrm{~N}_{3} \mathrm{PO}_{4}$ mixture ( $\mathrm{pH}$ 12.2) was used with 
kaolin, a slight decomposition occurred, as evidenced by the fact that a small amount of aluminum went into solution. The equilibrium $\mathrm{pH}$ was 10.51. No aluminum was found in the filtrate from the $\mathrm{KCl}-\mathrm{KOH}-\mathrm{H}_{3} \mathrm{PO}_{4}$ ( $\mathrm{pH} 10.0$ ) treatment of kaolinite. In this case, however, the final $\mathrm{pH}$ dropped to 8.0. The data indicate that a wide ratio of solution to kaolinite and $\mathrm{pH}$ values of 10 or above are necessary before there is any appreciable decomposition on the alkaline side. The data indicate that the decomposition of kaolinite occurs at $\mathrm{pH}$ values outside the range for agricultural soils or for plant growth. Furthermore, any phosphate the kaolinite fixes, especially from a phosphate solution of low concentration (which would be the case in the soil even with liberal phosphate fertilization), is of low availability for plant use.

The exact effect of the oxalate ion is not clear. Russell and Prescott (42) found that dilute acids removed phosphates from a soil in the following order : $0.1 N$ oxalic $>0.1 N$ citric $>0.1 \mathrm{~N} \mathrm{H}_{2} \mathrm{SO}_{4}>0.1 N \mathrm{HNO}_{3}=0.1 \mathrm{~N} \mathrm{HCl}$; and that soils adsorbed phosphorus from sodium phosphate readily in the presence of $\mathrm{HCl}$ and $\mathrm{HNO}_{3}$ but to a notably less extent in the presence of an equivalent concentration of citric acid. They infer that acids like citric and oxalic satisfy the adsorption capacity of the soil and leave it with little power to take up phosphoric acid. Demolon and Bastisse (8) found that the presence of citrate and oxalate ions reduced the amount of $\mathrm{P}_{2} \mathrm{O}_{5}$ fixed by a soil. No data were presented to show the fixation of the citrate or oxalate ions though a partition of these ions to the phosphate ion was given as a reason for the lower power to fix phosphate. Lichtenwalner, Plenner, and Gordon (25) found that citric acid had no effect in removing phosphate which had been fixed by an iron hydrogel, but it peptized the aluminum hydrogel and removed some adsorbed phosphate from the latter. Weiser (49) reported that organic matter was apparently effective in deactivating iron- and aluminum-fixing materials.

The data presented in tables 15 and 16 substantiate the above observations that the presence of oxalate ions (or organic matter) reduce phosphate fixation, but they do not substantiate a strict stoichiometric relation in the fixation process.

\section{COMPARISON OF KAOLINITE WITH OTHER CLAY MATERIALS}

One-gram samples of kaolinite and H-bentonite were shaken intermittently for 1 week with $50 \mathrm{cc} \mathrm{KH}_{2} \mathrm{PO}_{4}$ solution containing $98.55 \mathrm{mg}$ of $\mathrm{PO}_{4}$. The suspensions were centrifuged, and the clear filtrates were analyzed. One-gram Volclay ${ }^{\circ}$ samples were shaken continuously on a

\footnotetext{
${ }^{\circ}$ Volclay is a trade name for bentonite found near Belle Fourche, S. D., and supplied by the American Colloid Company.
} 
roller for 24 hours with a similar solution and allowed to stand 2 days before being centrifuged.

TABLE 18

The Fixation of Phosphates by Different Clay Materials

\begin{tabular}{|c|c|c|c|c|}
\hline \multicolumn{2}{|c|}{ Reaction* } & \multirow{2}{*}{$\begin{array}{l}\mathrm{PO}_{4} \text { fixed } \\
\text { per } 100 \text { grams } \\
\text { of kaolinite }\end{array}$} & \multirow{2}{*}{$\begin{array}{c}\mathrm{PO}_{4} \text { fixed } \\
\text { per } 100 \text { grams } \\
\text { of } \mathrm{H} \text {-bentonite }\end{array}$} & \multirow{2}{*}{$\begin{array}{c}\mathrm{PO}_{4} \text { fixed } \\
\text { per } 100 \text { grams } \\
\text { of Volclay }\end{array}$} \\
\hline $\begin{array}{l}\text { Original } \\
\text { solution }\end{array}$ & $\begin{array}{c}\text { Kaolinite } \\
\text { filtrate }\end{array}$ & & & \\
\hline $\begin{array}{l}p H \\
\mathbf{4 . 5 4}\end{array}$ & $\begin{array}{c}p H \\
6.10\end{array}$ & $\begin{array}{c}m g \\
3,384\end{array}$ & $\begin{array}{c}m g \\
1,510\end{array}$ & $\begin{array}{c}m g \\
689\end{array}$ \\
\hline 6.08 & 6.36 & 3,056 & 1,407 & $\ldots$ \\
\hline 6.38 & 6.54 & 2,759 & 1,305 & $\ldots$ \\
\hline 6.75 & 6.85 & 2,452 & 1,407 & 516 \\
\hline 9.22 & 7.86 & 986 & 762 & 295 \\
\hline
\end{tabular}

* The $\mathrm{pH}$ of the H-bentonite and Volclay filtrates was not determined.

The data on fixation are given in table 18. Apparently kaolinite has a much higher capacity for fixing phosphate than has bentonite. Soils in which the clay is of a kaolinic character would therefore require a higher rate of phosphate fertilization in order to give increased yield if the kaolinite is finely divided.

\section{GREENHOUSE TESTS OF PHOSPHATE FERTILIZER ON AIKEN CLAY LOAM}

The Effect of Rate and Placement.-Two different rates of application of superphosphate were used in these experiments-280 pounds and 2,800 pounds per acre. Each 2-gallon glazed earthenware pot contained 8,000 grams of Aiken clay loam. No drainage was allowed to occur from the pots. In one series the phosphate was thoroughly mixed with all of the soil; and in the other series it was mixed with the upper 3,000 grams. The phosphate was applied only once, at the beginning of the experiment. At each planting date, 25 ce of $M \mathrm{Ca}\left(\mathrm{NO}_{3}\right)_{2}$ and a like amount of $M$ $\mathrm{KNO}_{3}$ were added to each pot. Tomatoes, barley, and vetch were used as the major crops, with buckwheat introduced in cases where the other crops were failures or did not seem to be giving much growth. All treatments were in triplicate.

The plants were harvested when the first blossoms appeared. Only the tops of the plants were used in determining the phosphate removed. The roots were left in the soil.

Tomatoes were a failure with the lower application of phosphate, and barley did not grow very well; hence, buckwheat was substituted later. From the data (table 19), buckwheat appears to be able to do much better than either tomatoes or barley. This is in accord with general field 
observations. All of the crops were able to make a fair growth when the rate of application of superphosphate was 2,800 pounds per acre. In a general way, the data bear out the conclusion that the efficiency of superphosphate is slightly higher where locally placed in the soil. The results also show that for some crops a nominal application of superphosphate (280 pounds per acre) on this soil is valueless, and to get response for

TABLE 19

The Recovery of Phosphate from Aiken Ciay Loam by Various Crops (Averages of triplicate treatments)

\begin{tabular}{|c|c|c|c|c|c|}
\hline \multirow{2}{*}{$P$ applied } & \multirow{2}{*}{ Crop sequences* } & \multicolumn{2}{|c|}{$P$ recovered } & \multicolumn{2}{|c|}{ Total $P$ recovered } \\
\hline & & Major crop & Buckwheat & Amount & Percentage $\dagger$ \\
\hline \multirow[t]{3}{*}{$m g$} & ( T T Bu Bu. & $\begin{array}{l}m g \\
0.07\end{array}$ & $\begin{array}{l}m g \\
4.98\end{array}$ & $\begin{array}{l}m g \\
5.05\end{array}$ & $\begin{array}{c}\text { per cent } \\
\ldots \ldots\end{array}$ \\
\hline & $\{\mathrm{B}$ B B Bu... & 1.61 & 1.28 & 2.89 & $\ldots$ \\
\hline & ( v v v v... & 10.38 & $\cdots$ & 10.38 & $\cdots+$ \\
\hline \multirow{3}{*}{$\begin{array}{c}125.75 \text { mixed } \\
\text { throughout } \\
\text { soil }\end{array}$} & ( T T Bu Bu. . & 0.19 & 9.51 & 9.70 & 3.70 \\
\hline & $\{$ B B B Bu.... & 15.62 & 16.00 & 31.62 & 22.85 \\
\hline & V v v v ................ & 28.46 & $\ldots$ & 28.46 & 14.38 \\
\hline \multirow{3}{*}{$\begin{array}{c}125.75 \text { in } \\
\text { upper layer }\end{array}$} & ( T T Bu Bu... & 0.49 & 11.68 & 12.17 & 5.66 \\
\hline & B B B Bu.... & 11.57 & 9.47 & 21.04 & 14.43 \\
\hline & V V V v............. & 31.08 & $\ldots \ldots$ & 31.08 & 16.46 \\
\hline \multirow{3}{*}{$\begin{array}{c}1,257.5 \text { mixed } \\
\text { throughout } \\
\text { soil }\end{array}$} & (Tomatoes (4 crops). . & 76.54 & $\ldots \ldots$ & 76.54 & 6.08 \\
\hline & $\{$ Barley (4 crops).... & 67.80 & $\ldots$ & 67.80 & 5.22 \\
\hline & (Vetch (4 crops)... & 105.19 & $\ldots$ & 105.19 & 7.54 \\
\hline \multirow{3}{*}{$\begin{array}{l}1,257.5 \text { in } \\
\text { upper layer }\end{array}$} & (Tomatoes (4 crops). . & 134.65 & $\ldots \ldots$ & 134.65 & 10.70 \\
\hline & $\{$ Barley $(4$ crops $) \ldots \ldots \ldots \ldots \ldots$ & 109.80 & $\ldots \ldots$ & 109.80 & 8.56 \\
\hline & Vetch $(4$ crops $) \ldots \ldots \ldots \ldots \ldots$ & 119.92 & $\ldots$ & 119.92 & 8.71 \\
\hline
\end{tabular}

* $\mathrm{T}=$ Tomatoes, $\mathrm{B}=$ Barley, $\mathrm{V}=$ Vetch, and $\mathrm{Bu}=$ Buckwheat.

† The percentage recovery is calculated after deducting the amount of phosphorus present in crops grown on unfertilized soil; in the case of 4 crops of tomatoes or barley, the deduction is based on the assumption that the recovery by 4 crops is proportionate to that by 2 or 3 crops.

these crops, large applications must be made. Investigations (43) have shown that for certain soils small applications of soluble phosphate fertilizers give no response, while a much higher rate of application often gives good results.

The Effect of Soil Reaction.-The reaction of the Aiken clay loam was modified by the use of dilute $\mathrm{H}_{2} \mathrm{SO}_{4}, \mathrm{CaCO}_{3}$, and $\mathrm{Na}_{2} \mathrm{CO}_{3}$. The $\mathrm{CaCO}_{3}$ and $\mathrm{Na}_{2} \mathrm{CO}_{3}$ were mixed with the soil by rolling the soil back and forth several times. The dilute $\mathrm{H}_{2} \mathrm{SO}_{4}$ was sprayed on thin layers of the soil ; after which the soil was allowed to come to equilibrium with the acid. The acidulation process was repeated until the equilibrium mixtures had the desired $\mathrm{pH}$. Triple superphosphate at the rate of 2,800 pounds per acre was thoroughly mixed with the soil. This was equivalent to 
$3,142 \mathrm{mg}$ of phosphorus per 2-gallon pot holding 8,000 grams of soil. All treatments were in triplicate.

TABLE 20

The Efrect of Reaction on the Recovery of Applied Phosphate to Aiken Clay Loam

(Averages of triplicate treatments)

\begin{tabular}{|c|c|c|c|c|c|c|c|c|c|}
\hline \multirow{3}{*}{ Reaction of soil } & \multicolumn{3}{|c|}{ Tomatoes* } & \multicolumn{3}{|c|}{ Barley* } & \multicolumn{3}{|c|}{ Vetch* } \\
\hline & \multirow{2}{*}{$\begin{array}{l}\text { Total } \\
\text { yield }\end{array}$} & \multicolumn{2}{|c|}{$\mathrm{P}$ recovered } & \multirow{2}{*}{$\begin{array}{l}\text { Total } \\
\text { yield }\end{array}$} & \multicolumn{2}{|c|}{$P$ recovered } & \multirow{2}{*}{$\begin{array}{l}\text { Total } \\
\text { yield }\end{array}$} & \multicolumn{2}{|c|}{$P$ recovered } \\
\hline & & Amount & $\underset{\text { cent† }}{\text { Per }}$ & & Amount & $\underset{\text { cent }}{\text { Per }}$ & & Amount & $\underset{\text { cent }}{\text { Per }}$ \\
\hline $\begin{array}{r}p H \\
4.0 \ldots \ldots \ldots\end{array}$ & $\begin{array}{c}\text { grams } \\
0.00\end{array}$ & $m g$ & $\begin{array}{c}\text { per cent } \\
\ldots .\end{array}$ & $\begin{array}{c}\text { grams } \\
0.00\end{array}$ & $\begin{array}{c}m g \\
\ldots \ldots\end{array}$ & $\begin{array}{c}\text { per cent } \\
\ldots .\end{array}$ & $\begin{array}{c}\text { grams } \\
0.00\end{array}$ & $\begin{array}{c}m g \\
\ldots \ldots\end{array}$ & $\begin{array}{c}\text { per cent } \\
\ldots .\end{array}$ \\
\hline $5.0 \ldots \ldots \ldots$ & 44.59 & 93.71 & 2.98 & 46.66 & 129.21 & 4.11 & 17.09 & 36.21 & 1.15 \\
\hline $5.4 \ldots \ldots \ldots$ & 76.95 & 145.90 & 4.64 & 31.77 & 88.65 & 2.82 & 16.81 & 42.55 & 1.35 \\
\hline $6.0 \ddagger \ldots . . .$. & 74.75 & 166.12 & 5.29 & 72.75 & 165.61 & 5.27 & 32.47 & 65.90 & 2.10 \\
\hline 7.8 & & & & & & & & & \\
\hline $\mathrm{CaCO}_{3} \S$ & 70.53 & 158.17 & 5.03 & 66.93 & 163.80 & 5.21 & 26.54 & 57.34 & 1.82 \\
\hline $\mathrm{Na}_{2} \mathrm{CO}_{3} \mathrm{q}$ & 36.14 & 81.12 & 2.58 & 73.07 & 131.94 & 4.20 & 12.11 & 30.89 & 0.98 \\
\hline
\end{tabular}

* In all cases, except for tomatoes in the pH 5.4 series, 3 crops were grown. In the exception noted, only 2 crops were grown during the period of the experiment.

$\dagger$ On the basis of $3,142 \mathrm{mg}$ of phosphorus added per pot. No deductions were made for the soil, since other experiments indicated that this amount was negligible.

$\ddagger$ Natural soil. $\quad \& 80$ grams per pot. $\quad$ I $400 \mathrm{cc} M \mathrm{Na}_{2} \mathrm{CO}_{3}$ per pot.

Where $\mathrm{Na}_{2} \mathrm{CO}_{3}$ was used, the soil had an undesirable physical condition which tended to prevent water penetration. As a result, aeration was deficient, especially after the addition of moisture to the soil. The data in general (table 20) indicate that within the reaction range suit-

TABLE 21

The Effect of Source of Nitrogen on the Recovery of Phosphorus From TRIPLE SUPERPHOSPhate BY TOMaTOES

(Averages of triplicate treatments)

\begin{tabular}{l|c|c|c|c|c}
\hline \hline \multirow{2}{*}{ Treatment } & \multicolumn{3}{c|}{ Yield } & \multicolumn{2}{c}{ Total P recovered } \\
\cline { 2 - 5 } & First crop & Second crop & Third crop & Amount & Per cent* \\
\hline & grams & grams & grams & mg & per cent \\
Triple superphosphate only $\ldots \ldots \ldots$ & 23.72 & 3.44 & 4.82 & 107.02 & 3.41 \\
Triple superphosphate $+\left(\mathrm{NH}_{4}\right)_{2} \mathrm{SO}_{4}$ & 34.66 & 26.02 & 7.72 & 156.13 & 4.97 \\
Triple superphosphate $+\mathrm{Ca}\left(\mathrm{NO}_{3}\right)_{2} \ldots$ & 36.91 & 29.92 & 11.76 & 159.91 & 5.09 \\
& & & & & \\
\hline
\end{tabular}

* On the basis of 3,142 mg of phosphorus added per pot. No deductions were made for that furnished by the soil without fertilization since other experiments indicated this was negligible.

able for crop production, there is little to choose. Apparently a reaction between $\mathrm{pH} 6$ and $\mathrm{pH} 7$ is most satisfactory, and nothing would be gained in the Aiken clay loam by changing the present soil reaction.

The Effect of Source of Nitrogen.-Triple superphosphate at the rate of 2,800 pounds per acre was thoroughly mixed with virgin Aiken clay 
loam. This was equivalent to $3,142 \mathrm{mg}$ of phosphorus per 2-gallon pot holding 8,000 grams of soil. In some cases, the nitrogen was supplied as

TABLE 22

The Effect of a Good Starting Medium on Phosphate Removal by Tomatoes (Averages of triplicate treatments)

\begin{tabular}{|c|c|c|c|c|c|}
\hline \multirow{2}{*}{ Series } & \multirow{2}{*}{ Medium of growth* } & \multicolumn{3}{|c|}{ Yield } & \multirow{2}{*}{$\mathbf{P}$ in crops } \\
\hline & & First crop & Second crop & Third crop & \\
\hline \multirow[b]{2}{*}{1} & & grams & grams & grams & $m g$ \\
\hline & $\begin{array}{r}5,000 \text { grams Aiken clay loam beneath } 3,000 \\
\text { grams Fresno } \ldots \ldots \ldots \ldots \ldots \ldots \ldots \ldots\end{array}$ & 22.91 & 16.42 & 9.64 & 89.64 \\
\hline 2 & $\begin{array}{r}5,000 \text { grams sand } \dagger \text { beneath } 3,000 \text { grams } \\
\text { Fresno fine sandy loam } \ldots \ldots \ldots \ldots \ldots \ldots\end{array}$ & 14.50 & 10.37 & 3.22 & 56.08 \\
\hline 3 & 8,000 grams Aiken clay loam. ........... & 0.02 & 0.05 & 0.05 & 0.10 \\
\hline 4 & 8,000 grams Fresno fine sandy loam..... & 25.29 & 26.96 & 14.82 & 178.92 \\
\hline
\end{tabular}

* Each pot received $25 \mathrm{ec}$ of $M \mathrm{Ca}\left(\mathrm{NO}_{3}\right)_{2}$ applied to the surface at each planting date.

t At the beginning of the experiments and at the beginning of each succeeding cropping period, $500 \mathrm{cc}$ of a solution $0.005 M$ in $\mathrm{Ca}\left(\mathrm{NO}_{3}\right)_{2}, 0.005 M$ in $\mathrm{KNO}_{3}$, and $0.002 M$ in $\mathrm{MgSO}_{4}$ were added to the sand; $2 \mathrm{cc}$ of iron tartrate were also added.

$\left(\mathrm{NH}_{4}\right)_{2} \mathrm{SO}_{4}$, and in others as $\mathrm{Ca}\left(\mathrm{NO}_{3}\right)_{2}$. At the beginning of growth at each planting date, 25 ec of $M\left(\mathrm{NH}_{4}\right)_{2} \mathrm{SO}_{4}$ or $\mathrm{Ca}\left(\mathrm{NO}_{3}\right)_{2}$ was added. All treatments were in triplicate. Tomatoes were grown on the soil.

Where the triple superphosphate was used alone, the foliage had a yellow color, which indicates nitrogen deficiency, especially after the first period. Even the first crop showed some nitrogen deficiency. The

TABLE 23

The Recovery by Tomatoes of Phosphorus Supplied to Aiken Clay Loam by Superphosphate of Difrerent Particle Sizes (Averages of duplicate treatments)

\begin{tabular}{|c|c|c|c|}
\hline Size of particle & $\begin{array}{l}\text { Oven-dry } \\
\text { weight of crops }\end{array}$ & $\begin{array}{l}\text { Applied } \\
\text { phosphorus } \\
\text { recovered } \\
\text { by plants }\end{array}$ & $\begin{array}{l}\text { Ratio to } \\
\text { granulated } \\
\text { super- } \\
\text { phosphate }\end{array}$ \\
\hline & grams & per cent & $: 1.00$ \\
\hline Granulated superphosphate. & 26.13 & 7.32 & 1.00 \\
\hline Up to 10 mesh ............ & 40.45 & 16.22 & 2.21 \\
\hline 10 to 20 mesh... & 33.07 & 11.95 & 1.63 \\
\hline 20 to 60 mesh... & 21.80 & 5.90 & 0.80 \\
\hline 60 to 100 mesh... & 18.75 & 5.09 & 0.69 \\
\hline 100 to 200 mesh. & 10.89 & 2.31 & 0.31 \\
\hline Finer.......... & 11.65 & 3.23 & 0.44 \\
\hline
\end{tabular}

influence of the triple superphosphate extended over two cropping periods where the nitrogen deficiency was corrected (table 21), but beyond this the applied phosphate had little effect. The third crop in all cases was very spindly and showed phosphate deficiency. No choice can be made between the use of $\left(\mathrm{NH}_{4}\right)_{2} \mathrm{SO}_{4}$ and $\mathrm{Ca}\left(\mathrm{NO}_{3}\right)_{2}$ as the source of nitrogen with triple superphosphate on this soil. 
The Effect of a Good Starting Medium.-Three crops of tomatoes were grown in pots containing a total of 8,000 grams of Fresno fine sandy loam, Aiken clay loam, or combinations of these with each other or with sand. Series 1 consisted of 5,000 grams of Aiken clay loam placed in the bottom of the pot; on top of and unmixed with this were 3,000 grams of

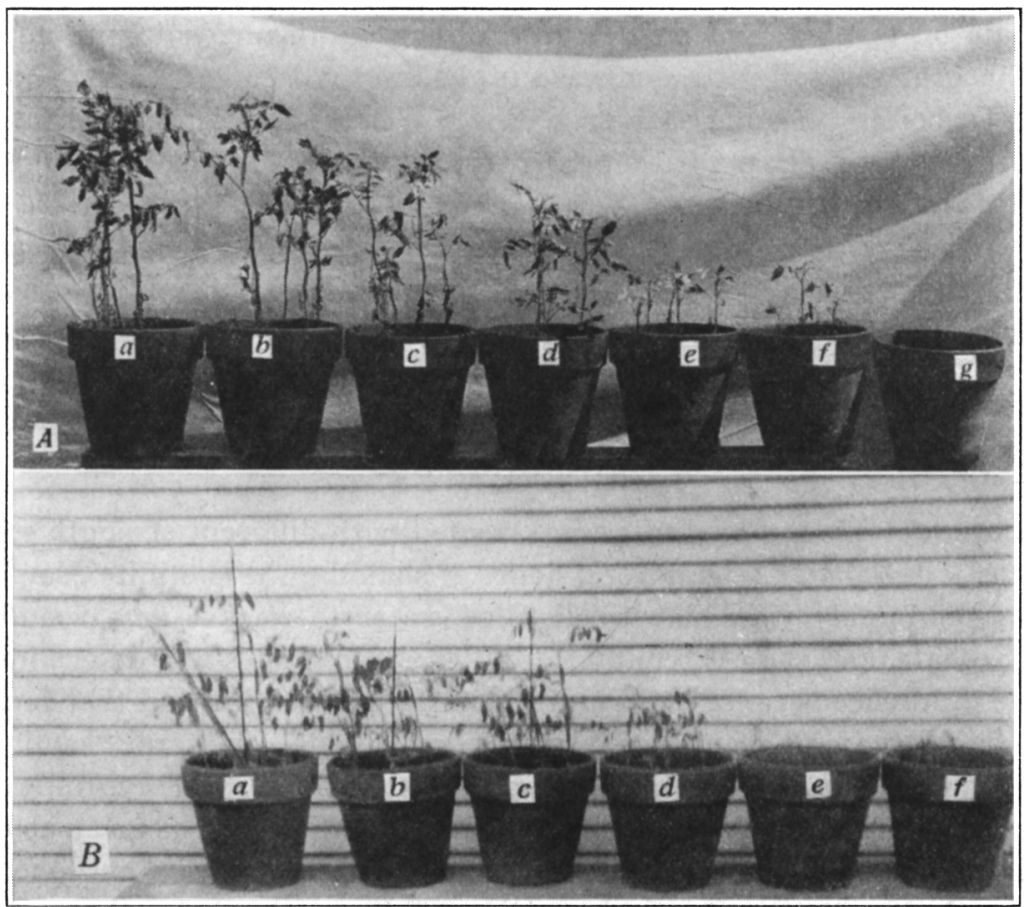

Fig. 6.-The influence of the size of superphosphate particles on the growth of tomatoes on Aiken clay loam: $A$, second crop; $B$, sixth crop. The size of particles of superphosphate applied to the various pots was as follows: $a$, coarser than 10 mesh ; $b, 10-20$ mesh ; $c, 20-60$ mesh ; $d, 60-100$ mesh ; $e, 100-200$ mesh ; $f$, finer than 200 mesh. In series $A$, pot $g$ contained Aiken soil with no phosphate.

Fresno soil. Series 2 consisted of 5,000 grams of acid-washed white sand in the bottom of the pot; on top of and unmixed with this were 3,000 grams of Fresno soil. Series 3 was Aiken soil only. Series 4 was Fresno soil only. The Fresno and Aiken soils contained 0.16 per cent and 0.18 per cent of total $\mathrm{PO}_{4}$ respectively. All treatments were in triplicate.

The tomato plant was unable to make any growth on the Aiken soil, but it made a nice growth on the Fresno soil (table 22). The root systems were extensive both in the Aiken soil below the Fresno soil and in the sand below the Fresno soil; more phosphorus was recovered from the plants on the former than on the latter, but just how much of the extra 
phosphorus was taken from the Aiken soil cannot be determined from these data. The results indicate that if the plant is given a good start, it can probably secure more phosphorus than it normally does from unfertilized virgin Aiken soil.

The Effect of Size of Superphosphate Particles.-Aiken clay loam in 7,000-gram lots was placed in 10-inch pots and 2.8 grams of superphosphate of various-sized particles were thoroughly mixed in the upper 2,000 grams of soil. Nitrogen was supplied in the form of $\mathrm{Ca}\left(\mathrm{NO}_{3}\right)_{2}$ and $\mathrm{KNO}_{3}$ before planting each crop. Seven consecutive crops of tomatoes were grown in each pot without any further phosphate treatment. Treatments were in duplicate.

Table 23 gives the condensed results. They indicate clearly that coarse particles are to be preferred over fine particles of superphosphate for such soils (fig. 6).

\section{GREENHOUSE TESTS OF COMPARATIVE VALUE OF SUPERPHOSPHATE AND "KAOLINITE PHOSPHATES"}

Samples of ground kaolinite were treated with different strength solutions of $\mathrm{KH}_{2} \mathrm{PO}_{4}$. After several hours of shaking, the kaolinite complex was thoroughly washed with distilled water to remove any occluded phosphate, and the $\mathrm{PO}_{4}$ content of all of the leachates was determined. The difference between the $\mathrm{PO}_{4}$ in the original solution and that found in the leachate was considered as fixed phosphate. The term "kaolinite phosphate" is used to designate the phosphated kaolinite. Three different degrees of saturation were secured with kaolinite treated as given above. These were used in sand cultures and compared with the phosphorus furnished by 1 gram of superphosphate. The amount of phosphorus furnished in all cases was made equivalent to that in the superphosphate by adjusting the amount of phosphated kaolinite. Each pot held 5,000 grams of pure sand. The phosphate was thoroughly mixed throughout the sand. To each container, after planting tomato seed, was added $800 \mathrm{cc}$ of Hoagland's solution minus $\mathrm{PO}_{4}$. Five plants were allowed to grow in each pot. The growth period was of 45 days' duration (January 7 to February 21, 1938). The plants grown on the superphosphate treatment were in bloom at the time of harvest. The oven-dry weights of the plants were as follows :

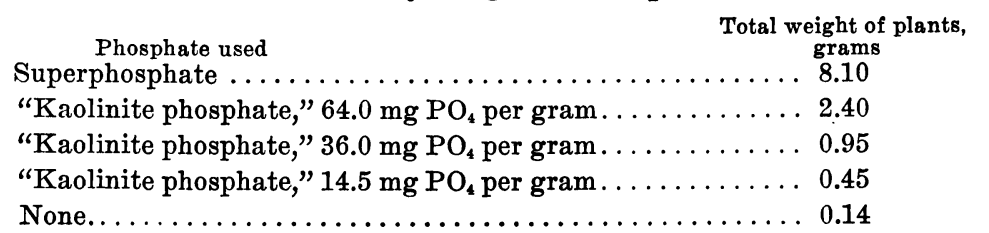


The comparative growth with the various treatments is shown in figure 7.

The data indicate that the availability of the adsorbed phosphate varies with the degree of saturation of the adsorbed complex. If a light

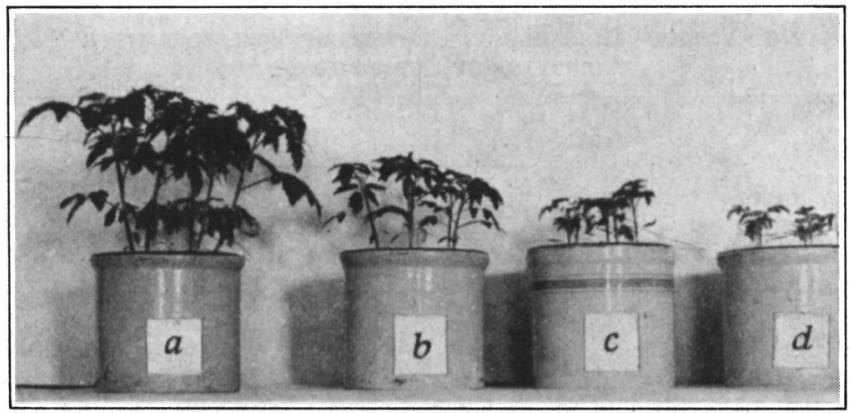

Fig. 7.-The comparative growth of tomatoes in sand cultures where the phosphorus is furnished as: $a$, superphosphate; $b$, strongly saturated "kaolinite phosphate"; $c$, medium-saturated "kaolinite phosphate"; $d$, weakly saturated "kaolinite phosphate."

fertilizer application is made on a soil, the phosphate of which is controlled by the kaolinite complex, there will be practically no response by certain crops. Only when the kaolinite is more highly saturated will the plant be able to secure its needed phosphate for growth, and even then the growth period must be of considerable length in order to secure full development of the plant.

\section{GREENHOUSE TESTS OF THE EFFECT OF VARIOUS COLLOIDS ON SUPERPHOSPHATE EFFICIENCY}

Greenhouse experiments were conducted with sand mixtures and Aiken clay loam mixtures in Mason quart jars. The total air-dry weight of material in each jar was 1,250 grams except in the case of the Aiken soil, where it was 860 grams. The treatments were conducted in duplicate. The colloid and superphosphate were thoroughly mixed in the jar. The kaolinite used in the 1 per cent mixture had been ground in a ball mill for 7 days. The Volclay was 200-mesh material. The Aiken colloid had been pulverized in a mortar until it was quite fine. Natural Aiken clay loam was used without any previous treatment. One tomato plant was grown per jar. At the beginning of the experiment, $200 \mathrm{cc}$ of Hoagland's solution minus $\mathrm{PO}_{4}$ was added to each jar.

The results (table 24 and fig. 8) fully justify the conclusion that kaolinic clays are very effective in fixing phosphates in a form not readily 
accessible to plants when limited amounts of soluble phosphates are applied. On the other hand, a soil containing montmorillonitic (bentonitic) clay should be more effective in supplying plants with their needed phosphate. The plants in the sand culture were in bloom when harvested.

TABLE 24

EFFect of Various Colloids on Growth of Tomatoes with Various ADDITIONS OF SUPERPHOSPHATE

\begin{tabular}{|c|c|c|c|c|c|}
\hline \multirow{3}{*}{ Culture } & \multicolumn{5}{|c|}{ Superphosphate additions* } \\
\hline & None & $50 \mathrm{mg}$ & $100 \mathrm{mg}$ & $150 \mathrm{mg}$ & $200 \mathrm{mg}$ \\
\hline & \multicolumn{5}{|c|}{ Average total oven-dry weight of tomato plants } \\
\hline & grams & grams & grams & grams & grams \\
\hline Sand only ................. & 0.02 & 1.00 & 1.60 & 1.80 & 1.75 \\
\hline Sand +1 per cent Volclay...... & 0.02 & 1.45 & 1.45 & 1.40 & 1.50 \\
\hline Sand +1 per cent Aiken colloid...... & $0.01+$ & 0.13 & 0.90 & 1.42 & 1.65 \\
\hline Sand +20 per cent crushed kaolinite... & 0.02 & 0.02 & 0.02 & $0.02+$ & 0.04 \\
\hline Sand +1 per cent finely divided kaolinite & 0.01 & $0.01+$ & 0.02 & 0.03 & 0.03 \\
\hline Aiken clay loam $\ldots \ldots \ldots \ldots \ldots \ldots \ldots$ & 0.01 & $0.01+$ & 0.02 & 0.03 & 0.03 \\
\hline
\end{tabular}

* Considering the volume weights of sand and Aiken clay loam, these applications of superphosphate are approximately equivalent to $80,160,240$, and 320 pounds per acre, respectively.

\section{DISCUSSION OF RESULTS}

Certain soils contain colloidal material which by X-ray pattern analysis has been shown to be kaolinic in character. Other investigations, where $\mathrm{X}$-ray facilities have not been available, have shown the colloidal fraction of a great many soils to have a low silica : sesquioxide ratio, suggesting the presence of a kaolinic type of clay. These soils are known to have a high capacity to fix soluble phosphate fertilizers in forms not readily available for plants. Since most of these soils are red in color, they have been assumed to be high in iron. In some cases this is actually the case, but in others the iron content is not so great as the color of the soil would indicate. Iron has been considered the chief factor in the phosphateadsorbing system of these soils. Certain results render such an assumption questionable.

The presence of free ionic iron in any appreciable amount in the soil occurs only under extreme conditions of soil reaction. Much the same may be said of aluminum. Experiments show (curve $b$ in figs. 1 and 2, pp. 348 and 349) that iron phosphate formed by these ions would be removed from solutions within the usual reaction range of soils. But such experiments do not prove that ionic iron is present in soils to fix applied soluble phosphates rapidly; and hence, do not give the real picture of existing soil conditions. 
Iron and aluminum hydrosols and hydrogels are known to have the ability to remove soluble phosphates from solution under certain conditions (curve $a$ in figs. 1 and 2). Hydrolysis of the freshly prepared iron complexes occurs, however, and at $\mathrm{pH} 6$ and above there is a considerable release of $\mathrm{PO}_{4}$ even in the presence of an excess of iron. The $\mathrm{PO}_{4}$ released under these conditions by the hydrosol is much greater than that present

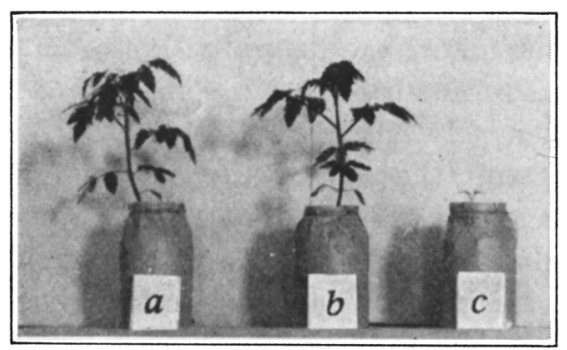

Fig. 8.-The comparative growth of tomatoes as influenced by phosphate availability in: $a$, sand only $+200 \mathrm{mg}$ superphosphate; $b$, sand +1 per cent Volclay + $200 \mathrm{mg}$ superphosphate; $c$, sand +1 per cent kaolinite $+200 \mathrm{mg}$ superphosphate. (Other nutrients were derived from Hoagland's solution minus $\mathrm{PO}_{*}$.)

in the soil solution under similar conditions, and is not in accord with the ability of plants to grow on such soils. Other factors must, therefore, be involved.

The experiments with a good grade of kaolinite as shown by X-ray pattern data (fig. 3, p. 357) indicate that this material has a high phosphate-fixing power when ground in a ball mill for a few days. The clay particles of soils are colloidal in nature and it is permissible to assume that at least some of the kaolinite is colloidally dispersed. Russell (41) states that under natural conditions kaolinite is not so finely divided as some of the other clay minerals. The data in table 8 (p. 357) indicate that a soil weighing $2,000,000$ pounds per surface 6 inches in depth and containing 1 per cent of finely divided kaolinite would be able to fix 2,058 pounds of $\mathrm{PO}_{4}$ under conditions similar to those in the experiment.

The fixation by kaolinite is extremely high for all concentrations of soluble phosphates in the reaction range of agricultural soils. However, the product formed varies in phosphate saturation according to the concentration (amount of phosphate per unit volume of solution) of phosphate at its disposal. When these "kaolinite phosphates" of different degrees of saturation are used as a source of phosphate for plants in pot cultures, the response is directly proportional to the degree of satura- 
tion. This means that where this kind of adsorbing system is controlling the phosphate equilibrium in the soil, a small application is ineffective; and to secure results, a much higher rate of phosphate application must be employed.

The fixation is greatest at acid reactions. When the exposed solution contains $\mathrm{H}_{2} \mathrm{PO}_{4}$ ions, the fixation is great. This has a very important bearing, because experiments $(23,32)$ indicate that this phosphate ion is the one which plants absorb most rapidly. If the colloidal system of the soil prefers this kind of ion for fixation, soils having this kind of adsorbing system are extremely efficient in "competing" with the plant for phosphorus. As a result, the plant, because of its limited root area, is at a great disadvantage and suffers because of this competition.

Decomposition data indicate that the valences necessary for the fixation depend upon aluminum. When the reaction is such that much aluminum appears in solution, the fixation of phosphate by the kaolinite is decreased. This, however, does not take place in the usual soil reaction range and although of theoretical value in determining the nature of the fixation is not of practical agricultural interest. When the concentration of the $\mathrm{OH}$ ion is increased, less and less phosphate is fixed. When the $\mathrm{OH}$ ion concentration attains a certain strength, somewhere above $\mathrm{pH} 10$, there is little or no more fixation; but an actual breakdown of the clay complex occurs. Likewise, if the $\mathrm{H}$ ion concentration is increased sufficiently, somewhere below $\mathrm{pH} \mathrm{2,} \mathrm{decomposition} \mathrm{occurs,} \mathrm{as} \mathrm{would}$ be expected from the use of strong acids in general analytical work. Between these extremes, the phosphate fixed increases with a decrease in $\mathrm{pH}$, and cation fixation decreases.

Colloids having a high silica : sesquioxide ratio have a lower capacity to fix phosphates, as shown by both chemical and greenhouse work. This is in general accord with the work of other investigators.

Gile (18) found in studying the influence of various soil colloids on the efficiency of superphosphate that soils having colloids of low silica : sesquioxide ratios depressed the efficiency more than those having a higher ratio. Furthermore, the colloids which depressed superphosphate most were those of smallest base-exchange capacity. These properties suggest that the high phosphate-fixing colloids studied by Gile were kaolinic in character.

Kaolin is formed by weathering processes (39) and is probably present in some of its forms in all soils containing colloids of a low silica : sesquioxide ratio. Not only have such soils, therefore, active sesquioxides in more or less abundance, but also the kaolin in them is in a highly divided state as a result of the pronounced weathering, which augments phos- 
phate retention greatly. The presence of kaolin in this condition severely handicaps the ability of plants to secure phosphorus either from the supply in the soil itself or from that of applied soluble phosphates, which are rapidly converted into a highly inaccessible form.

The other clay minerals studied exhibit less fixing power, but even so their presence in soils is an important contributing factor to phosphate fixation. According to our investigations, the efficiency of applied soluble phosphates is a function of the kind of clay minerals present in the soil : if the clay is kaolinlike, a low efficiency is inevitable, while soils with a montmorillonitic clay complex will have a higher degree of phosphate efficiency.

Coarsely ground superphosphate is better than finely divided superphosphate for these kaolinic soils. There are two reasons for this : First, such material is less rapidly fixed in the soil ; second, the fixed phosphate is in more highly saturated zones, and as such, is of higher availability than it would be if it were fixed from finer phosphate particles, where the concentration of the solution surrounding the clay is lower. The first reason accounts for the better results in the first crops, and in all probability the later crops are benefited largely because of the second factor. Local application also would have produced more highly saturated colloids.

\section{SUMMARY}

Soils with a kaolinic type of clay have a high capacity to fix soluble phosphates, as is shown by both chemical and greenhouse experiments. This is in accord with field results.

Phosphate fixation by the various iron systems alone is not considered sufficient to account for all of the properties that these soils show with respect to phosphate availability.

Kaolinite when ground to colloidal dimensions has a high phosphatefixing capacity.

The fixation is greatest at acid reactions, which indicates that the $\mathrm{H}_{2} \mathrm{PO}_{4}$ ion is the most favored phosphate ion for the reaction.

An increase in base-exchange capacity accompanies the increase in phosphate fixed.

Greenhouse experiments show that the availability of the phosphate in "kaolinite phosphate" is directly proportional to the degree of phosphate saturation. This is taken to indicate that a light phosphate fertilizer application would be ineffective on soils having a kaolinic kind of clay.

Even a very low percentage of kaolinite, if in a colloidal condition in a soil, will tie up phosphate and make it unavailable for plants. 
Greenhouse results substantiate the laboratory data in showing that bentonite (Volclay) has a much lower capacity to fix phosphorus in an inaccessible form for plant growth than does colloidal kaolinite.

The results are considered sufficient to explain why soils with a kaolinic type of clay have a high capacity to fix phosphate and a low phosphate availability as measured by plant growth.

\section{ACKNOWLEDGMENTS}

The writer wishes to express his gratitude for assistance rendered by all the members of the committee in charge of the thesis, and especially to Professors J. S. Burd and D. R. Hoagland for their many kindly criticisms and suggestions during the progress of the work. An indebtedness to Professor W. H. Dore for the X-ray work necessary in producing figure 3 is also gratefully acknowledged. 


\section{LITERA'TURE CITED}

\section{Association of Official Agricultural Chemists.}

1930. Official and tentative methods of analysis. $564 \mathrm{p}$. Washington, D. C.

2. BRADFIELD, RICHARD.

1931. The colloidal chemistry of soils. p. 569-90. In : Alexander, Jerome. Colloid chemistry. vol. 3. The Chemical Catalog Co., Inc., New York, N. Y. (Original not read; reported by Scarseth, 44.)

3. Brown, I. C., and H. G. BYers.

1932. The fractionation, composition, and hypothetical constitution of certain colloids derived from the great soil groups. U. S. Dept. Agr. Tech. Bul. $319: 1-43$.

4. BUehrer, T. F.

1932. The physico-chemical relationships of soil phosphates. Arizona Agr. Exp.

Sta. Tech. Bul. 42:155-212.

5. CoMber, N. M.

1925. The rôle of the electronegative ions in the relations between soils and electrolytes. Faraday Soc. Trans. 20:1-6.

6. Davis, L. E.

1935. Sorption of phosphates by non-calcareous Hawaiian soils. Soil Sci. 40: 129-58.

7. Dean, L. A.

1934. Electrodialysis as a means of studying the nature of soil phosphates. Soil Sci. 37:253-66.

8. Demolon, A., and E. Bastisse.

1934. Contribution a l'etude de la mechanique chimique des anions dans le sol. Ann. Agron. n. s. 4:53.

9. Doughty, J. L.

1931. Phosphorus studies in Alberta soils. Scientific Agr. 12:43-51.

10. Ellett, W. B., and H. H. HiLl.

1917. A ten-year study of the effect of fertilizers on the soluble plant food in the soil and on the crop yield. Virginia Agr. Exp. Sta. Tech. Bul. 13: $46-72$.

11. Fisher, E. A.

1922. The phenomena of absorption in soils: a eritical discussion of the hypotheses put forward. Faraday Soc. Trans. 17:305-16.

12. FORD, M. C.

1932. The distribution, availability, and nature of the phosphates in certain Kentucky soils. Jour. Amer. Soc. Agron. 25:395-410.

13. FORD, M. C.

1933. The nature of phosphate fixation in soils. Jour. Amer. Soc. Agron. $25: 134-44$.

14. FRAPS, G. S.

1922. The fixation of phosphoric acid by the soil. Texas Agr. Exp. Sta. Bul. $304: 1-22$. 
15. GaArder, T., and O. Grahl-Nielsen.

1936. Die Bindung der Phosphorsaure in Erdboden: II. Untersuchungen aus Westnorwegen. Vestl. F̈ors. Forsksstation. Meddl. (Bergen) 5(4) (NR 18):1-109.

16. Ghosh, J. C., and P. B. Bhattacharyya.

1930. Removal of ions from solutions of calcium dihydrogen phosphate by treatment with hydrous gels of alumina, silica, and their mixtures. Soil Sei. 29:311-22.

17. GILBERT, B. E.

1931. The Forty-third Annual Report of the Director of the Rhode Island Agricultural Experiment Station. Rhode Island State College Bul. 26: 28-49. (See especially p. 40.)

18. GiLe, P. L.

1933. The effect of different colloidal soil materials on the efficiency of superphosphate. U. S. Dept. Agr. Tech. Bul. 371:1-49.

19. Gordon, N. E., and E. B. Starkey.

1922. Influence of soil colloids on availability of salts. Soil Sci. 14:1-7.

20. HARRISON, W. H., and S. DAS.

1921. The retention of soluble phosphates in calcareous and noncalcareous soils. India Dept. Agr. Memoirs Chem. Series 5:195-236.

21. HeCK, A. P.

1934. Phosphate fixation and penetration in soils. Soil Sci. 37:343-55.

22. HibBaRd, P. L.

1935. Factors influencing phosphate fixation in soils. Soil Sci. 39:337-58.

23. Hoagland, D. R., and A. R. Davis.

1929. The intake and accumulation of electrolytes in plant cells. Protoplasma 6:610-26.

24. Kelley, W. P., and W. H. Dore.

1937. The clay minerals of California soils. Soil Science of America Proc. 2:115-20.

25. Lichtenwalner, D. C., A. L. Plenner, and N. E. Gordon.

1923. Adsorption and replacement of plant food in colloidal oxides of iron and aluminum. Soil Sci. 15:157-65.

26. Marais, J. S.

1922. The comparative agricultural value of insoluble mineral phosphates of aluminum, iron, and calcium. Soil Sci. 13:355-409.

27. MatTSON, S.

1927. Anionic and eationic adsorption by soil colloidal materials of varying $\mathrm{SiO}_{2} / \mathrm{Al}_{2} \mathrm{O}_{3}+\mathrm{Fe}_{2} \mathrm{O}_{3}$ ratio. First Internatl. Cong. Soil Sci. [Washington] Proc. 2(Comm. II) :199-211.

28. Mattson, $\mathrm{S}$.

1930-1931. Laws of soil colloidal behavior: III and IV. Isoelectric precipitates. Soil Sci. 30:459-95; 31:57-77.

29. Mattson, $\mathrm{S}$.

1931. Laws of soil colloidal behavior: V. Ion adsorption and exchange. Soil Sci. 31:311-31. 
30. MATTSON, S.

1931. Laws of soil colloidal behavior: VI. Amphoteric behavior. Soil Sci. 32: 343-65.

31. Mattson, S., and A. J. Pugh.

1934. Laws of soil colloidal behavior: XIV. The electrokinetics of hydrous oxides and their ionic exchange. Soil Sci. 38:299-313.

32. McGeorge, W. T., and J. F. Breazeale.

1932. Studies of iron, aluminum, and organic phosphates and phosphate fixation in calcareous soils. Arizona Agr. Exp. Sta. Tech. Bul. 40:59-111.

33. Pugh, A. J.

1934. Laws of soil colloidal behavior: I. Aging of colloids and base exchange. Soil Sci. 37:403-27.

34. PUGH, A. J.

1934. Laws of soil colloidal behavior: II. Ionic exchange with hydroxides. Soil Sci. 38:161-73.

35. Pugh, A. J.

1934. Laws of soil colloidal behavior: III. Colloidal phosphates. Soil Sci. 38: 315-34.

36. Pugh, A. J., and M. S. DU ToIT.

1936. The composition and ionic exchange of ferric silicates and phosphates. Soil Sci. 41:417-31.

37. RAVIKovitCH, S.

1934. Anion exchange: I. Adsorption of the phosphoric acid ions by soils. Soil Sei. 38:219-39.

38. RAVIKovitCH, S.

1934. Anion exchange: II. Liberation of the phosphoric acid ions adsorbed by soils. Soil Sci. 38:279-90.

39. Ross, C. S., and P. F. KERR.

1931. The kaolin minerals. U. S. Geol. Survey Prof. Paper 165E:151-76.

40. Roszmann, C. A.

1927. Retention of phosphorus by soil colloids. Soil Sci. 24:465-74.

41. RusselL, E. J.

1937. Soil conditions and plant growth. 7th ed. 655 p. Longmans, Green and Co., New York, N. Y.

42. Russeld, E. J., and J. A. Prescott.

1916. The reaction between dilute acids and the phosphorus compounds of the soil. Jour. Agr. Sei. 8:65-110.

43. SCARSETH, G. D.

1932. Morphological, greenhouse, and chemical studies of the Black Belt soils of Alabama. Alabama Agr. Exp. Sta. Bul. 237:1-48.

44. SCARSETH, G. D.

1935. The mechanism of phosphate retention by natural alumino-silicate colloids. Jour. Amer. Soc. Agron. 27:596-616.

45. Starkey, E. B., and N. E. Gordon.

1922. Influence of hydrogen ion concentration on the adsorption of plant food by soil colloids. Soil Sci. 14:449-57. 
46. TEAKLe, L. J. H.

1928. Phosphate in the soil solution as affected by reaction and cation concentrations. Soil Sci. 25:143-62.

47. Tiulin, A. F.

1935. Critical zones of absorbed ions and their availability for plant life. Internatl. Soc. Soil Sci. Trans., Soviet section, vol. A, p. 70-78.

48. Truog, E.

1916. The utilization of phosphates by agricultural crops, including a new theory regarding the feeding power of plants. Wisconsin Agr. Exp. Sta. Research Bul. 41:1-50.

49. WEISER, V. L.

1933. Fixation and penetration of phosphates in Vermont soils. Vermont Agr. Exp. Sta. Bul. 356:1-31.

50. Whitson, A. R., and C. W. Stoddard.

1909. Factors influencing the phosphate content of soils. Wisconsin Agr. Exp. Sta. Research Bul. 2:41-60.

51. Wiley, R. C., and N. E. GoRdon.

1923. Availability of adsorbed phosphorus. Soil Sci. 15:371-72. 